\title{
GELENEKSEL URFA KONUTUNUN KONUKEVİNE DÖNÜŞÜMÜ: HACI ABO EVI
}

Saide AÇANAL (saide-acanal@hotmail.com)

Beykent Üniversitesi, Fen Bilimleri Enstitüsü, İç Mimarlık Tezli Yüksek Lisans Öğrencisi, Istanbul, Türkiye

Bilge GÖNÜL (bilgeyildirimgonul@gmail.com)

Beykent Üniversitesi, Mühendislik Mimarlık Fakültesi, İ̧ Mimarlık Bölümü, İstanbul, Türkiye

\section{ÖZET}

Geleneksel Urfa konutları, bulundukları bölgenin tarihini, mimarisini, kültürünü ve yaşam tarzını yansıtan önemli yapılardır. Mekansal açıdan değerlendirildiğinde bu konutların özgün işlevini yer yer kaybettiği anlaşılmıştır. Ülkemizdeki toplumsal değişimlere bağlı olarak yerini modern konutlara bırakan tarihi konutların korunması açısından yeni işlevlerle kullanılmaları genel bir kabul görmektedir.

Özellikle kültür turizmi açısından önemi gün geçtikçe artan Urfa'daki geleneksel konutların konukevi olarak kullanımı yaygın bir yaklaşım haline gelmiştir. Geleneksel Urfa konutlarındaki işlev değişikliğinin mekansal açıdan değerlendirilmesi bu çalışmanın konusunu oluşturmaktadır. Farklı örnekler 1şığında geleneksel Urfa konutlarının konukevi olarak kullanımlarının mekansal olarak incelendiği bu çalışma, Hacı Abo Evi örneği ile detaylandırılmıştır.

$\mathrm{Bu}$ çalışmada, tarihi ve kültürel özellikleri ile bir turizm kenti olan Urfa'da, konaklama tesislerine ihtiyaç olabileceği düşünülerek, konukevi kullanımının geleneksel konutlara adaptasyonlarının, tarihi yapıların yapısal ve mekansal nitelikleri korunarak sağlanması gereği vurgulanmaktadır.

Anahtar Kelimeler: Hacı Abo, yeniden işlevlendirme, konukevi, Urfa konutlarl, restorasyon, koruma. 


\title{
TRANSFORMATION OF THE TRADITIONAL URFA HOUSE INTO THE GUEST HOUSE: HACI ABO HOUSE
}

Saide AÇANAL (saide-acanal@hotmail.com)

Beykent University, Institute of Sciences \& Engineering, Msc Student in Interior Architecture Department, Istanbul, Turkey

Bilge GÖNÜL (bilgeyildirimgonul@gmail.com)

Beykent University, Faculty of Engineering and Architecture, Interior Architecture Department, İstanbul, Turkey

\begin{abstract}
Traditional Urfa houses are important buildings that reflect the history, architecture, culture and life style of the region where they are located. When evaluated from the spatial features, it was understood that such houses have lost their original functions locally. Based on the social changes in our country, it is generally accepted that the historical houses that left their places to the modern houses should be used by the new functions for protection.

In particular, it is a common approach to use of the traditional houses as the guest houses in Urfa that is increasingly important in the cultural tourism. The subject of this study is to assess the functional changes in the traditional Urfa houses in terms of spatial features. Under the light of different samples, this study that is examined about reuse of the traditional Urfa houses as the guest houses in terms of spatially has been detailed by the example of Hac1 Abo House.

In this study, by considering the fact that the accommodation facilities will be requested in Urfa that is a tourism city by means of its historical and cultural specifications, it is emphasized that the adaptation of the guest houses utilization with the traditional houses should be provided by protecting their historical structures and spatial qualifications accordingly.
\end{abstract}

Keywords: Hacı Abo, refunctioning, guest house, Urfa houses, restoration, preserving. 


\section{GİRIŞ}

Tarihi yapılar, zamanla yıpranıp bozulabildiği gibi, işlevini de kaybedebilmektedirler. Toplumların sosyal ve kültürel yapılarının değişimi ile geleneksel konutlar özgün işlevini sürdürseler dahi çoğu zaman mekansal konfor şartları açısından yenilenmeyi gerektirmektedir. Kimi zaman ise özgün işlevin sürdürülebilirliği söz konusu olmayarak işlev değişikliği de gerekebilmektedir. Tarihi yapıların yeni işlev seçiminde çevresel ve yapısal değerler bir bütün olarak ele alınmalıdır.

$\mathrm{Bu}$ çalışmanın konusu, tarihi yapıları koruma kapsamında, geleneksel Urfa konutlarının yeniden işlevlendirilmesi açısından konukevine dönüşümünün irdelenmesine ilişkindir. Bu bağlamda, özgün Urfa konutları çevresel, mimari ve mekansal açıdan incelenerek, konukevine dönüşümleri değerlendirilmiştir.

$\mathrm{Bu}$ çalışmanın amacı; kültür mirası olan tarihi yapılarımızın korunmasına örnek teşkil edebilecek geleneksel Urfa konutlarının, yaşatılması ve sürdürülebilirliğinin sağlanabilmesi için, yeniden işlevlendirme kapsamında konukevi olarak kullanımının mekansal açıdan değerlendirilmesidir. $\mathrm{Bu}$ amaç doğrultusunda örnekler 1şığında irdelenen çalışma konusu restorasyon öncesi Hacı Abo Evi'nin, restorasyon sonrası konukevine dönüşümü kapsamında detaylandırılmıştır.

\section{GELENEKSEL URFA KONUTLARININ MEKANSAL AÇIDAN DEĞERLENDİRILMESI}

Şanlıurfa'nın tarihi dokusu içinde güçlü bir yapı kültürü oluşturan geleneksel konutlar, farklı kuşakların bir arada yaşadığ aile yapısına göre inşa edilmiştir. Yazları $40-45^{\circ} \mathrm{C}^{\prime}$ yi bulan sıcak ve kurak iklimin etkisiyle, Kuzey Mezopotamya süsleme ve yapım tekniklerinin yöre gereçleriyle biçimlenmesi, konut mimarisinde önemli etkenler oluşturmuştur [1]. Bunun yanı sıra toplumsal yapı, 
gelenekler ve yaşam tarzının da etkisiyle geleneksel konutlar, Şanlıurfa mimarisinde önemli bir yeri olan yapı tipleri olmuştur.

Urfa konutlarının dışa kapalı olması, iklimin ve geleneksel yaşam şeklinin mekansal yansıması olarak düşünülebilir. Ayrıca ev sahibinin ekonomik durumuyla bağlantılı olarak evin büyüklüğü, oda sayıları, süsleme ve bezemeleri farklılık göstermektedir.

\subsection{Geleneksel Urfa Konutlarının Mimari Özellikleri}

Geleneksel Urfa konutlarının mimari karakteristiğini oluşturan unsurlar olarak, iklim koşulları, coğrafik özellikleri, yaşam şekli ve geleneklerin yanı sıra bölgede yaşamış geçmiş medeniyetlerin de etkili olduğu bilinmektedir. Karakteristik planlama ilkesine sahip konutlar, yapısal olarak, kalın taş duvarları, düz çatı örtüsü, damları, tonozlu kemerleri ve bezeme tekniklerinin etkili olduğu bir mimari yapıya sahiptir.

Çevresel ve iklimsel açıdan Şanlıurfa bölgesi belirgin özelliklere sahiptir. Enlem olarak ekvatora yakın olan kentte karasal iklim hakimdir. Gece ile gündüz ve yaz ile kış mevsimlerinin ortalama sıcaklıkları arasında büyük farklar vardır. Bölgenin iklimsel özelliği, Şanlıurfa konutlarının malzeme seçimi ve mimari karakterinin biçimlenmesinde önemli rol oynamıştır. Üstü açık avlulara bakan, üç tarafı ve üstü kapalı olan eyvanlar, Urfa'daki geleneksel konutlarda iklimin ortaya çıkardığı karakteristik mekanlardır.
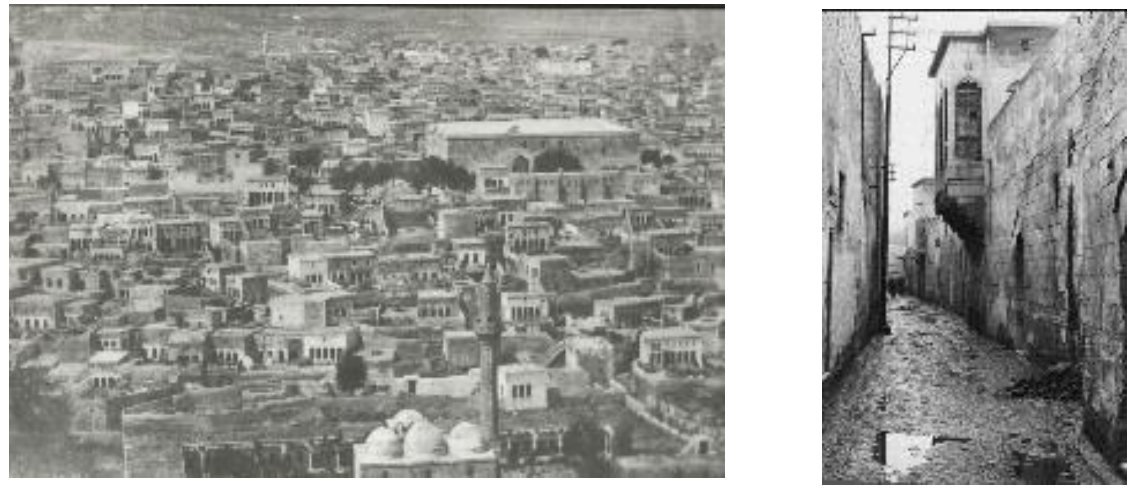

Şekil.1.19. Yüzyıl sonlarında Balıklıgöl ve çevresi (Kürkçüoğlu, A.C., Şanlıurfa'da Canlana Tarih,1995, Şanlıurfa Valiliği-Şurkav, Çevre Düzenleme ve Restorasyon Çalışmaları, 1990-1995, Birinci Basım, Şanlıurfa İli Kültür Eğitim Sanat ve Araştırma Vakfı yayınları: 11, Kültür Dizisi No:7, S:59)

Şekil.2. Eski Urfa sokaklarından görünüm (C. Kürkçüoğlu Arşivi) 
Kent ölçeğinde, geleneksel Urfa konutlarında izolasyon özelliği olan taş malzeme kullanılması, sık bir yerleşim düzeni içinde bitişik nizam konumlanmaları, konutları çevreleyen ve ortaklaşa kullanılan kalın yüksek duvarlar, üzeri kabaltılı sokaklar sıcaklığın etkisini azaltan genel çözümlerdir (Şekil.1, 2). Kabaltı; sokağın üstten tonozla örtülü olan bölümüdür (Şekil. 3). Genellikle düzgün olmayan geometrik sınırlar içinde yer alan konutları ayıran dar sokaklar kimi zaman da tedirbe denilen 1,5-2,5 m. genişliğinde, 5$15 \mathrm{~m}$ uzunluğunda çıkmazlarla son bulmaktadır (Şekil.4). Tetirbeler, evlerin sokak kapısı ile son bulmaktadır ve bu çıkmaz sokaklara mahallenin ana yollarından ayrılarak evlere uzanan özel yollar demek mümkündür [2]. Tetirbe içerisinde bir veya birden fazla evin girişi yer alabilmektedir. Konutlar toplumsal yapı gereği birbirini görmeyecek biçimde konumlandırılmıştır.
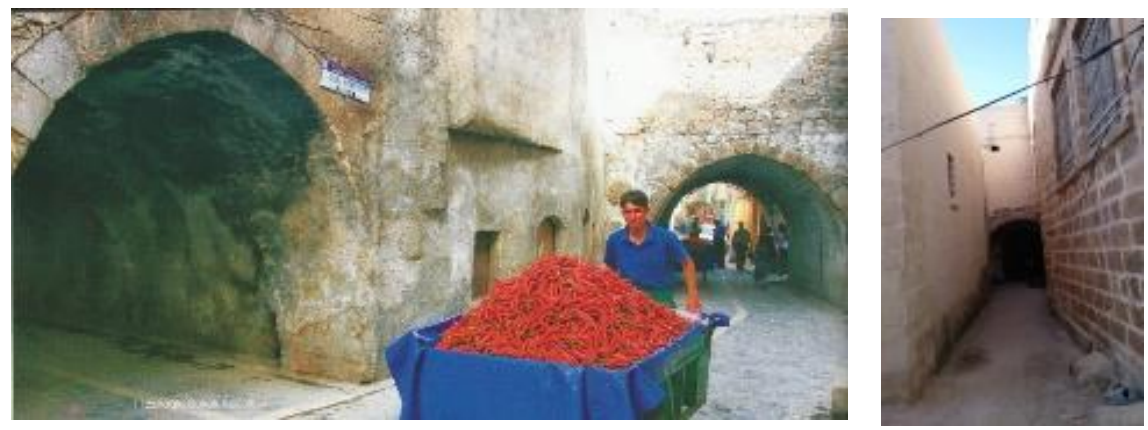

Şekil.3. Hızanoğlu sokak kabaltıları (Mızrak, R. ve Kürkçüoğlu, S., 2012, Şanlıurfa Kabaltıları (SABAT-Abbara), Şurkav Şanlıurfa Dergisi. Kültür Sanat Tarih ve Turizm. 5(13), 30-32)

Şekil.4. Kaleboynu sokak (S. Açanal Arşivi, 2014)

Planimetrik açıdan geleneksel Urfa konutları, geniş avluların yer aldığı içe dönük bir yapıya sahiptir. Konutların mekânsal açıdan haremlik ve selamlık olarak ayrışması belirgin bir plan özelliğidir.

Selamlık bölümünde, daha küçük bir avlu (hayat), bir veya iki oda, eyvan, ahır (develik) ve tuvalet bulunmaktadır. Gelen erkek misafirler selamlık kısmında ağırlanmaktadır. Genellikle harem kısmının görülebileceği kaygısıyla selamlık kısmı tek katlı planlanmıştır. Selamlık kısmı iki katlı yapılmış olsa bile ikinci kat harem bölümüne aittir [3]. 
Harem bölümünde ise, evin asıl bölümlerini oluşturan mekanlar bulunur. Daha geniş bir avlu (hayat), avlu içerisinde havuz, kuyu, çiçeklik ve çevresinde, eyvanlar, odalar, tandırlık (mutfak), zerzembe (kiler veya depo olarak kullanılan, avlu kotundan düşük kotta düzenlenen oda) ve hamam bulunmaktadır. En fazla iki katlı olan konutlarda harem her iki katta da yer alır. Tek avlulu örnekler de mevcuttur. Tek avlulu plan tiplerinde de, ortada bir avlu ve çevresine mekanlar dizilmiştir. Şekil.5' de yer alan örnek plan tipinde görüldügü gibi, zemin katta avlu ve çevresinde, kiler veya depo amaçlı kullanılan zerzembe, mutfak, odalar, ara kapısı ve evin giriş kapısı olduğu görülmektedir.
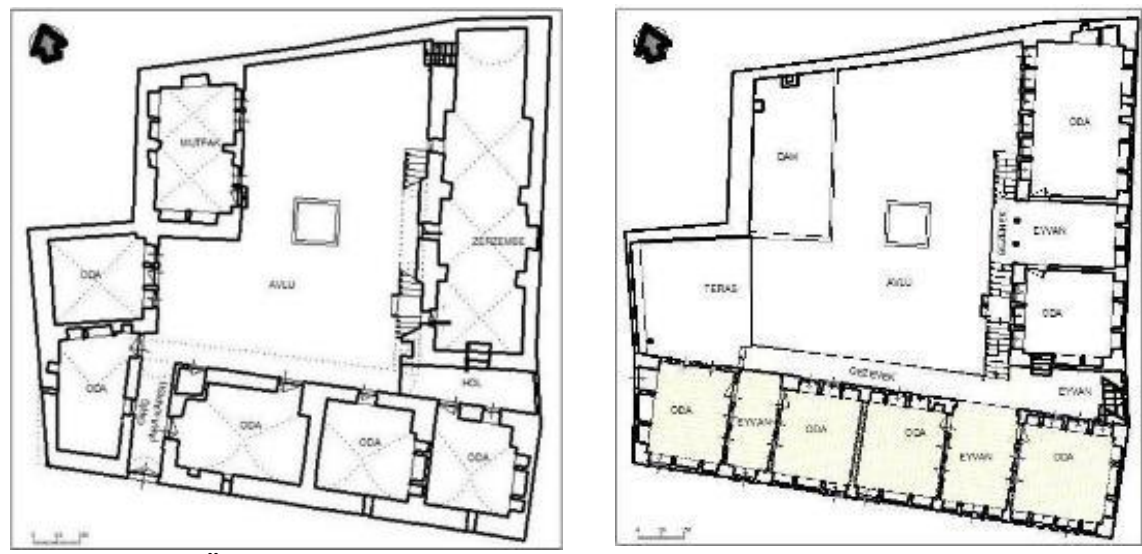

Şekil.5. Örnek zemin kat planı-Sezer Evi (C. Altıparmak Arşivi, 2010)

Şekil.6. Örnek birinci kat planı-Eyvan oda İlişkisi-Sezer Evi (C. Altıparmak Arşivi, 2010)

Şekil.6'da görülen Sezer Evi'nin birinci katında, cephesi kuzeye yönlendirilmiş iki eyvan, batıya yönlendirilmiş iki eyvan ve odalarla, bunların önünde gezenek ve avluya bağlanan merdiven olduğu görülmektedir. Gezenek; üst kattaki mekanların (odalar, eyvanlar) önünde bulunan, mekanlar arasındaki ulaşımı sağlayan ve merdiven ile avluya bağlanan üzeri açık geçiş alanıdır.

Cephe özellikleri açısından geleneksel Urfa konutlarının sokakla bağlantısı oldukça azdır. Kalın ve yüksek duvarların çevrelediği zemin kat cephelerinde açıklık bulunmamaktadır. Bunda içe dönük yaşam anlayışı ve iklim etkilidir. Sokağa bakan üst kat cephelerinde taş işlemeli konsol çıkmalar ve kabaltılar dikkat çekmektedir. Bunlar; sokağa hareket, konuta cephe zenginliği kazandırmaktadır (Şekil.7). 


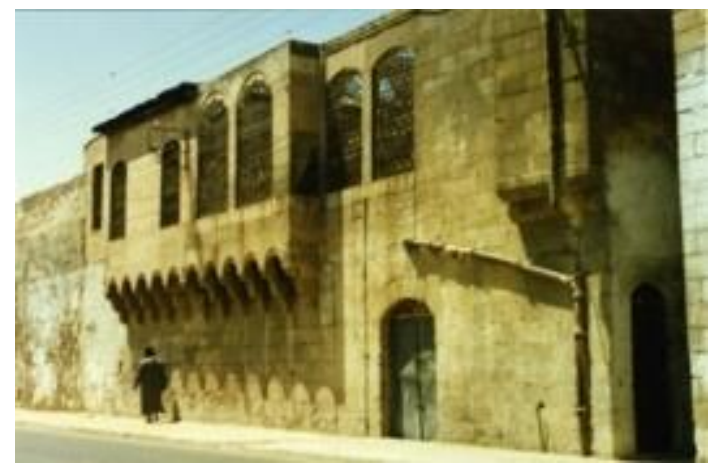

Şekil.7. Urfa konutun sokaktan görünümü (C. Kürkçüoğlu Arşivi)

Yapım teknikleri ve malzeme açısından Urfa konutları, geleneksel niteliklere sahiptir. Yığma sistemle inşa edilmiş konutlarda taş malzemenin yanı sıra, ahşap, demir ve saç malzemeler kullanılmıştır. Taş malzeme, taşıyıcı ve yalıtım özelliğinin yanı sıra bezemelerde de kullanılmıştır.

Geleneksel Urfa konutlarının çatıları genelde teras çatı (dam) şeklinde olup, üstleri sıkıştırılmış toprakla kapatılırdı. İçten, çapraz veya beşik tonozlu olan çatı örtüsü, cephede sivri, basık, yuvarlak kemerli bir görünüm almaktadır.

\section{2. Geleneksel Urfa Konutlarının İç Mekan Kimliği}

Geleneksel konutlar, çevresel ve iklimsel özellikler, ekonomik durum, gelenekler, toplumsal, sosyal ve kültürel yapının etkisi altında biçimlenir. Kullanıcı yapısı, yaşam ve mekan ilişkisi, mimari elemanlar ve yüzey bezeme biçimleri, geleneksel Urfa konutlarının iç mekan kimliğinin oluşumunda ve biçimlenmesinde önemli rol oynamıştır.

\section{Kullanıcı yapısı:}

Kullanıcı yapısı gereği, geleneksel Urfa konutlarında oda sayıları fazladır. Yeni evlenen erkek çocuklarına birer oda verilerek, anne, baba, çocuklar ve torunlar, ayrı aile birimleri olarak aynı evde yaşamlarını sürdürürlerdi. Bundan dolayı konutlarda odalar temel bir birim oluşturmaktadır. Mekansal olarak ayrışmayı gerektiren bir diğer durum cinsiyete bağlı kullanıcı yapısının gerektirdiği haremlik ve selamlık kullanımlarıdır. 


\section{Yaşam ve Mekan İlişkisi:}

Oda kullanımı açısından geleneksel Urfa konutları, karakteristik bir yapıya sahiptir. Konutun temel yaşama mekanı olan odalar, kendi başlarına günlük işlerin karşılanabildiği bütünlerdir [4]. Şanlıurfa konutlarında da odalar, eylemsel ayrışma göstermemektedir. Aynı odada hem yatma, hem yeme, içme, hem de oturma eylemleri gerçekleştirilmektedir. Bu anlamda oda; çok işlevli bir yaşam birimidir. Yüksek tavanlı odalar avluya bakan cephelerindeki pencerelerle konutlarda içe dönük bir yaşam imkanı sunmaktadır (Şekil.8). Bazı odaların tavanları, yıldız veya beşik tonoz şeklindedir (Şeki1.9). Odaların zemin kaplamaları Urfa taşındandır.
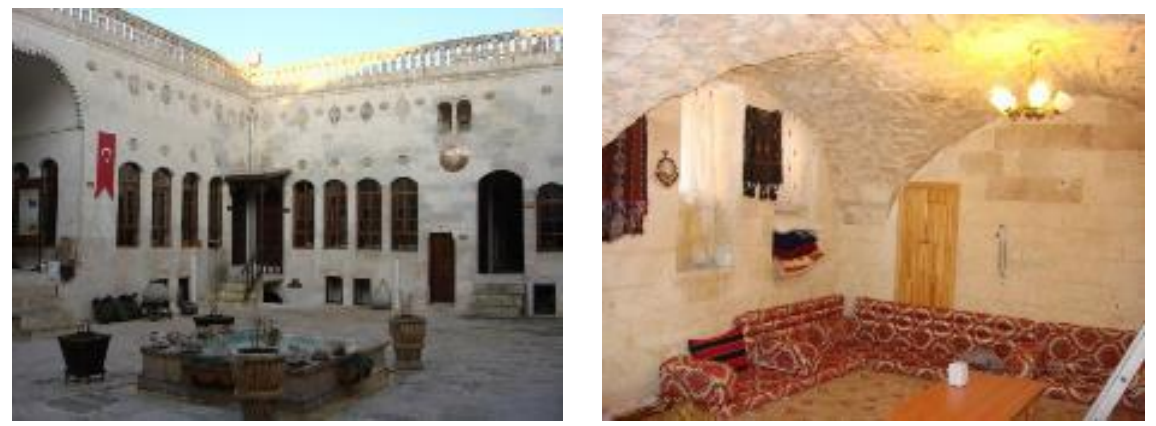

Şekil.8. Avluya bakan oda cepheleri, Hacibanlar Evi-Mutfak Müzesi (S. Açanal Arşivi, 2014)

Şekil.9. Tonozlu oda görünümü, Vezirhan Konukevi-Açanal Evi (S. Açanal Arşivi, 2013)
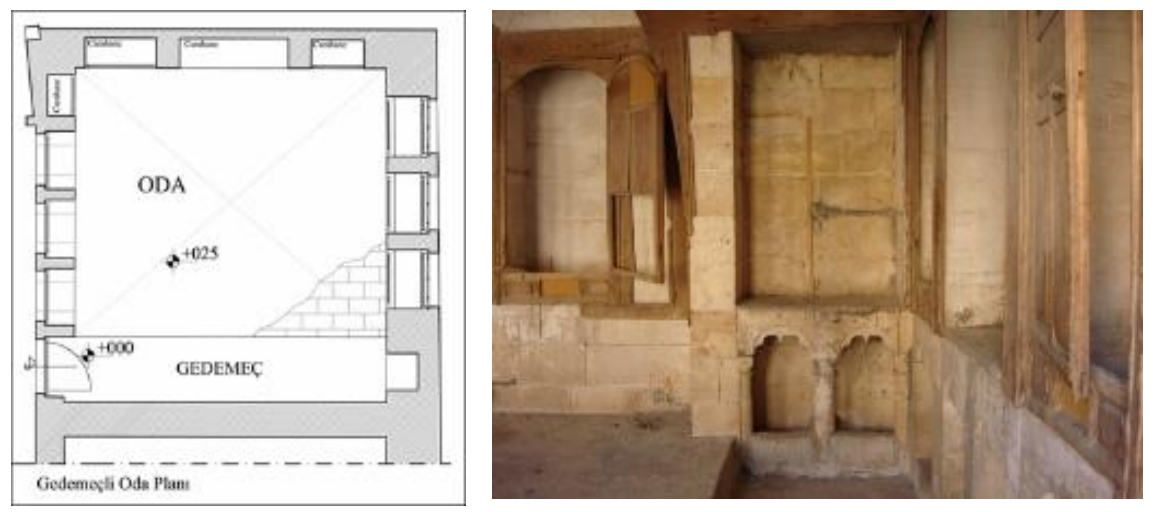

Şekil.10.a. Gedemeçli oda planı, proje S. Açanal, 2014

Şekil.10.b. Gedemę̧ ve nişler - Tevfik Saraç Evi (S. Açanal Arşivi, 2006) 
Geleneksel Urfa konutlarında, odanın girişindeki zeminden bir basamak kadar düşük kotta ayakkabıların çıkartıldığı bölümüne "gedemeç" denilmektedir. Gedemeç, odanın kısa kenarı doğrultusunda uzanır ve genişliği $100 \mathrm{~cm}$ kadardır (Şekil.10.a). Bazen gedemeçler oda boyunca uzanmayarak daha küçük mekansal bir bölüntü oluşturur. Genellikle gedemeç kısmında ayakkabıların konulduğu, yerden $25-40 \mathrm{~cm}$ kadar yüksekte nişler bulunur. $\mathrm{Bu}$ nişlerin genişliği genelde $50 \mathrm{~cm}$, yüksekliği ise $70-80 \mathrm{~cm}$ kadardır. Bazı evlerde ise bu nişlerin üzerinde, daha geniş bir niş daha bulunur (Şekil.10.b).

Odaların pencere olmayan duvarlarında camhane adı verilen, yaklaşık $60 \mathrm{~cm}$ derinliğinde nişler bulunmakta ve buraya yatak, yorgan, yastık, eşya ve elbiseler konulmaktadır. Evlerin bazılarında camhaneler, perdelerle, bazılarında ise camlı kapak veya camsız ahşap kepenklerle kapatılmıştır (Şekil.11). Urfa konutlarının iç mekanlarında yoğun ahşap kullanımı dikkat çekmektedir.
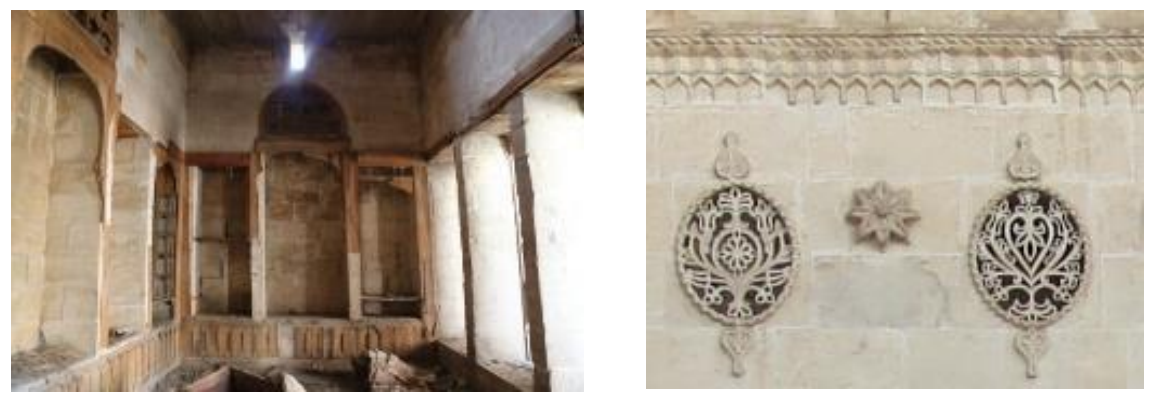

Şekil.11.Camhane ve dolap nişleri-Buluntu Hoca Evi (Şurkav Arşivi, 2013)

Şekil.12. Havalandırma takaları-Hacibanlar Evi-Mutfak Müzesi (S. Açanal Arşivi, 2014)

Odaların yüksek tavanları, dış ile görsel bağlantı sağlayan pencerelerin bitiminde hava ve 1ş1k almak amacıyla küçük açıklıkların yapılmasını olanaklı kılmıştır. Havalandırma takaları olarak anılan bu açıklıklar, değişken boyutlarda ve formlarda olup, bazı örnekleri kafes veya taş bezemelerle kaplıdır (Şekil.12).

Geleneksel Urfa konutlarında odalar, esnek yaşam imkanı sunmaktadır. Tüm aile aynı odada yatar, oturur ve yemek yerdi. Yemekler bakır siniler içinde, yer sofrası kurularak yenilirdi. Minderler ve yer yataklarında, gece yatılır, gündüz fazla yataklar kaldırılır ve oda günlük yaşama uygun hale getirilirdi. Minderler, yataklar ve diğer araç gereçlerin konulduğu gömme dolaplar ve 
camhaneler sabit, odada bulunan diğer elemanlar ise hareketli donatılardır. Bazı konutlarda ahşaptan yapılmış sandalye ve kerevet denilen divanlar bulunurdu. Isitma, soba veya mangallarla yapilırdı. Dönemin yaygın 1sınma sistemi, yaklaşık $50 \mathrm{~cm}$ yüksekliğinde bir ahşap kürsü ve mangal üzerine de bir yorgan konularak oluşturulurdu. Bu ısınma sistemi, Urfa'da tandır olarak anılmaktadır (Şekil.13).

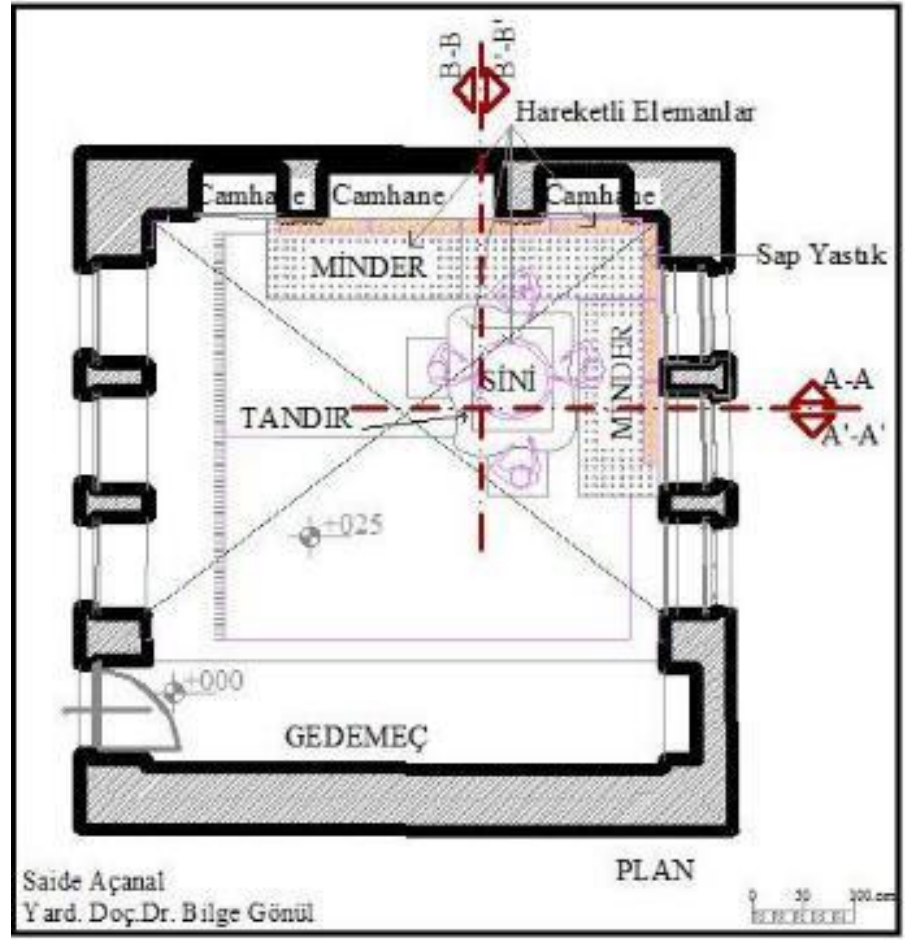

Şekil.13.a. Yaşam ünitesi olarak, Urfa konutunda oda planı

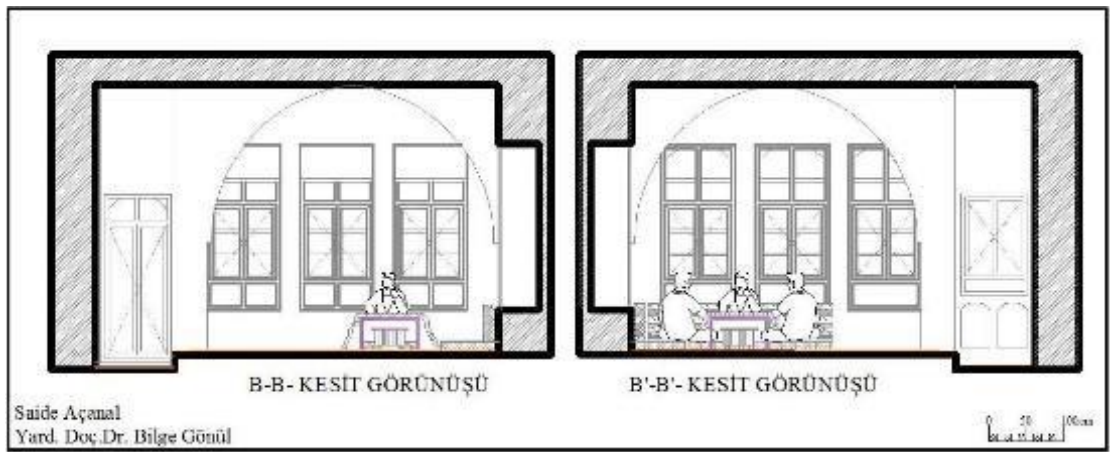

Şekil.13.b. Urfa konutunda oda iç mekan kesiti 
Avlu (Hayat) kullanımı ile geleneksel Urfa konutları, üretime katkı sağlamaktadır. Kimi zaman ailenin ihtiyacına yönelik, kimi zaman da gelir sağlamak amacıyla biber, salça gibi yiyeceklerin hazırlanması için avluların mekansal imkanlarından yararlanılmaktadır. Bunun yanı sıra avlular, konutlarda ortak yaşam imkanı sunan önemli mekanlardır. Konutun diğer birimleri avluyla ilişkilidir. Tek avlulu, iki avlulu ve bazen ikiden fazla avlusu olan konutlar da mevcuttur. Avlular, genellikle evlerin orta kismında yer alır ve üstü açıktır. Çevresine, oda, mutfak, eyvan, zerzembe (kiler, odunluk, depo) gibi mekanların dizildiği avlu, parselin geometrisine bağlı olarak, kare, dikdörtgen veya yamuk formlu olabilmektedir. Avlular konutlarda dış mekanla bağlantı kurulan, aynı zamanda içe dönük yaşam ve ortak kullanım imkanı sunan sosyalleşme mekanlarıdır. Odaların avluya bakan duvar yüzeylerinde, 1 şı takalarının üst kısımlarında, kuş takası adı verilen farklı biçimlerde nişler bulunur (Şekil.14).
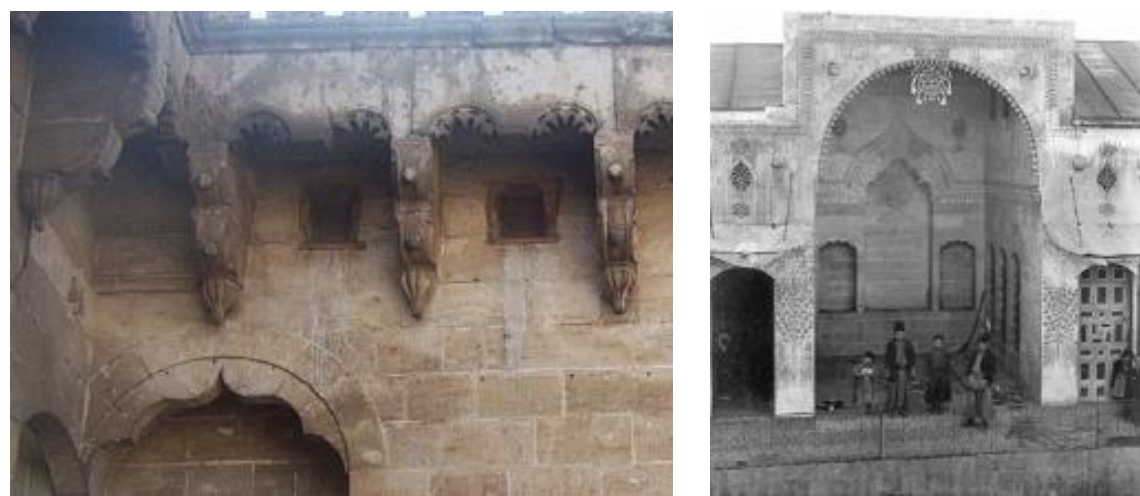

Şekil.14. Kuş Takaları - Tevfik Saraç Evi (S. Açanal Arşivi, 2005)

Şekil 15. Urfa konutunda eyvan (A. Öcal Arşivi)

Avlu içerisinde, taştan veya mermerden yapılmış, yuvarlak, kare, dikdörtgen veya sekizgen olarak çeşitli formlarda havuz yer alır. Zemin, "nahit" adı verilen kesme taşlarla kaplıdır. Peyzaj, avluların bir diğer belirgin karakteridir. Çeşitli meyve ağaçlarının yanı sıra, taşla (25-50 cm yüksekliğinde) veya demir korkulukla çevrilmiş çiçeklikler bulunmaktadır.

Eyvan kullanımı ile geleneksel Urfa konutlarında sicaktan korunmak için yarı açık mekanlar oluşturulmuştur. Eyvanlar odaların arasında yer alan, avlunun uzantısı niteliğindeki mekanlardır. Dikdörtgen formlu, üstü ve üç tarafı kapalı, genellikle 
kısa kenarı avluya açılan eyvanlar zengin motif ve bezemelere sahiptir (Şekil 15). Tek eyvanlı konutlar olabildiği gibi, birden fazla eyvanlı örnekler çoğunluktadır ve mevsimlik kullanımlara göre konumlandırılmıştır.

Servis mekanları genelde zemin katta yer alırlar. Bunlar; mutfak, zerzembeler ve develiklerdir. Yemek hazırlama eylemlerinin gerçekleştiği mutfaklar, eskiden tandırlık olarak anılmaktaydı. Tandırlık; evin harem bölümünde, avlu çevresinde bulunur, kare veya dikdörtgen planlıdır. Genelde giriş kısmı kemerli olup tavanları beşik veya çapraz tonoz denilen sistemle kapatılmıştır.

Zerzembeler; kışlık yiyeceklerin, yakacakların, bazı mutfak eşyalarının saklanma ve depolanmaları için, kiler ve depo amaçlı kullanılan mekanlardır. Bunlar, avlu kotundan düşük planlanmış ve böylece daha serin bir mekan oluşturulması sağlanmıştır, dikdörtgen planlıdır ve tavanları tonozla örtülüdür. Zerzembelerin girişi genelde avludandır ve mutfaktan zerzembeye geçilen örnekler de mevcuttur.

Develikler (Ahır); zemin katta, evin selamlık bölümünde bulunur. Dikdörtgen planl1, üstleri tonozla örtülüdür. Ev sahiplerinin ve konuklarının hayvanlarının barınakları olarak kullanılmıştır. Bazılarında duvar içlerinde, hayvanlara yem verme ve bağlama eylemleri için nişler vardır. Develerin kullanımı için olanlar diğer nişlere göre yerden daha yüksek yapılmıştır.

Islak mekanlar; hamam ve tuvaletlerdir. Harem bölümünde yer alan hamamlar bazı konutlarda daha özenli ve büyük iken, bazı konutlarda da daha sade ve küçük planlanmıştır. Hamam olmayan konutlarda yıkanma ihtiyacı mutfaklarda karşılanmaktadır. Tuvaletler; kapı arasında, avlu çevresinde veya merdiven altında yer alır. İki katlı konutların ikinci katında da tuvalet bulunan örnekler vardır.

\section{Mimari Elemanlar:}

Geleneksel Urfa evlerinde kullanılan mimari elemanlar, taşıdığ özellikleri ile konut sahibinin ekonomik düzeyini, yörenin ve dönemin sanat yaklaşımını, estetik anlayışını, kimliğini yansıtan belge niteliği taşımaktadırlar. Pencere ve kapılarda ahşap kullanılmıştır. Sokak giriş kapıları ahşap ve ahşap üzeri çinko, saç kaplamalı, üstü işlemeli, düz veya kemerlidir. 
Bazı kap1 üstlerinde kitabe bulunur. Genelde geniş alana sahip konutların giriş kapıları, deve ve atların geçebileceği yükseklikte ve iki kanatlıdır. $\mathrm{Bu}$ iki kanattan birinin içinde daha küçük bir kanat daha yer alır. Bu tip kapılara enikli kapı denir (Şekil.16). İnsanların geçebileceği boyutlardaki küçük kanat sıklıkla kullanılmakta, büyük kanatlar ise daha seyrek kullanılmaktadır. Kap1 ve pencereler sivri, basık kemerli veya düz formdadır. Pencere formları, genişlikleriyle orantılı yükseklikte, genelde çift kanatlı ve diştan demir parmaklıklıdır. İç kapılar ahşap veya ahşap doğramalı camekan şeklindedir (Şekil 17).

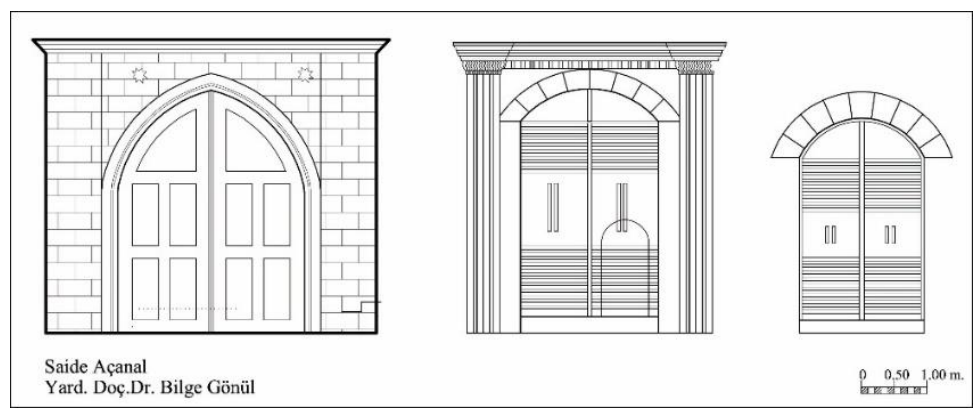

Şekil.16. Dış Kapı Örnekleri

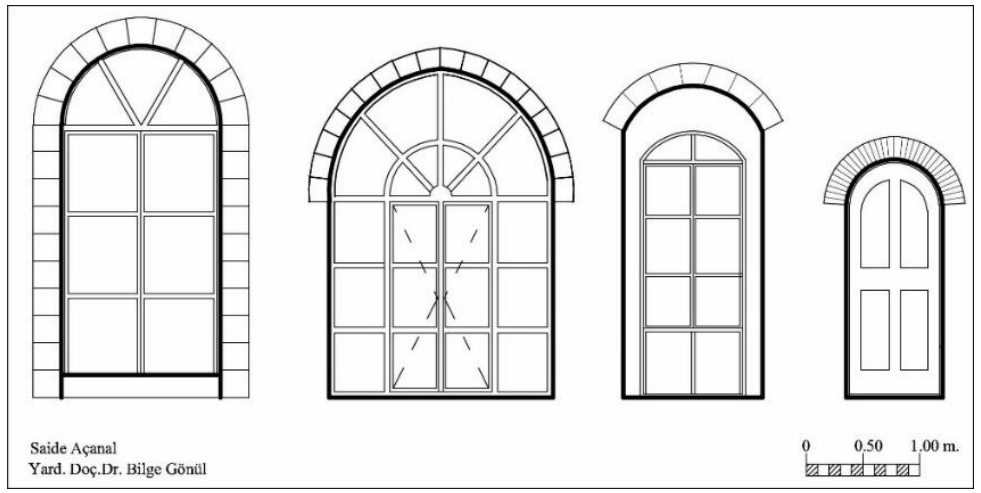

Şekil.17. İç kapı ve camekan örnekleri

\section{Urfa Konutunda Yüzey Bezeme Biçimleri:}

Taş süslemeler, Geleneksel Urfa konutlarında sıklıkla kullanılan bezeme biçimleridir. Yöreye özgü taş malzemenin ilk çıkartıldığında yumuşak ve kolay işlenebilir özellikte olması, havayla temas etmesi sonucu dayanıklılığının artması sebebiyle hem yapı malzemesi olarak, hem de süsleme sanatında tercih edilmektedir. Pencere üstlerinde, havalandırma takaları arasında veya üstlerinde, tamamen 
kapalı, bitkisel veya değişik bezemelerle kaplı, sadece estetik amaçlı yapılmış, kör takalar veya taş süslemeler bulunur. Bunun yanı sıra kemerler, gezenek altlarında ve sütunlarda da taş işlemeler kullanılmıştır (Şekil.18). Bunlar gerek dış gerekse de iç mekanlarda yer alabilmektedir.

Şekil.18.a. Taş süslemeler - Akyüzler Evi - İç mekanda taş bezeme örneği;

Şekil.18.b. Gezenek altı taş işleme; Şekil.18.c. Sütun süslemeleri (S. Açanal Arşivi, 2006)

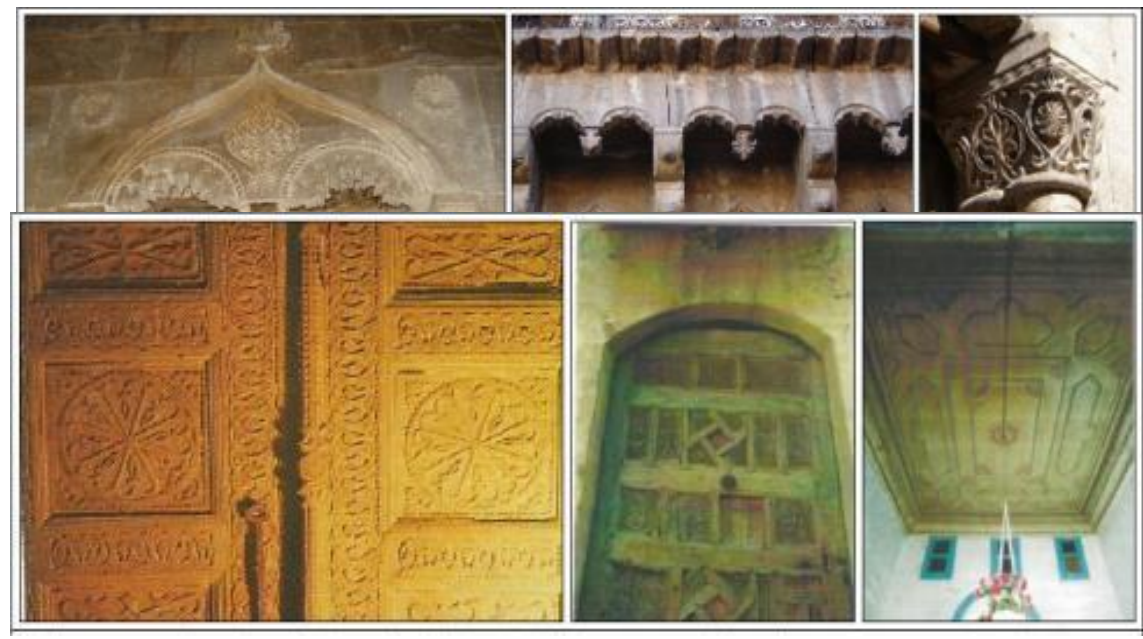

Ahşap süslemeler, dış cephelerde daha az görülmesine karşılık, iç mekanlarda sıklıkla rastlanmaktadır. Kapılarda, pencerelerde, camhane kepenklerinde ve tavan kaplamalarında yaygın olarak kullanılmaktadır (Şekil.19).

Şekil.19.a. Ahşap süslemeler, Ahşap oyma kapı kanadı (Oymak, M., Urfa ve Harran. Birinci Baskı. Ağustos 1998, 41-42)

Şekil.19.b. Ahşap süslemeler, Ahşap kapı ve tavan süslemeleri (Şurkav, 20 Ekim 2000, Şanlıurfa Kültür Sokağı Projesi, T.C. Şanlıurfa Valiliği, 39-40)

Dökme demir süslemeler, konutların giriş kapı tokmaklarında ve korkuluklarda sıklıkla kullanılan bezemelerdir (Şekil.20). Bazı konutlarda iki adet kapı tokmağı bulunmaktadır. Bir tanesi daha kalın ses çıkararak gelenin erkek olduğunu, diğeri ise daha ince ses çıkararak gelenin kadın olduğunu göstermektedir. 


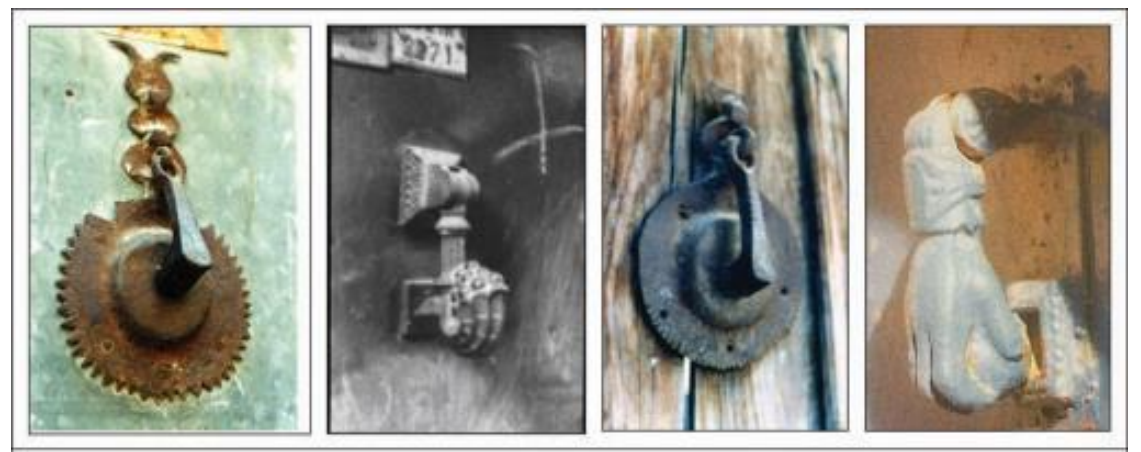

Şekil.20.a. ; Şekil.20.b; Şekil.20.c. Dökme demir süslemeler (C. Kürkçüoğlu Arşivi)

Şekil.20.d. Dökme demir süslemeler (Oymak, M., Urfa ve Harran. Birinci Bask1. Ağustos 1998)

\section{GELENEKSEL URFA KONUTLARININ KONUKEVINE DÖNÜŞÜMÜNÜN DEĞERLENDİRILMESI}

Urfa'daki konukevleri, tarihsel ve kültürel özelliklere sahip konutların, aslını bozmadan, bölgenin kültürel değerlerini yansıtarak, yöreye ait geleneklerin, yöresel faaliyetlerin ve hizmetlerin özgün ortamda sunulduğu, konaklamaya uygun işlevlerle kullanılan yapılar olarak tanımlanabilir.

Bir yapının onarılarak sağlığına kavuşturulmasının yapıya insan sıcaklığının kazandırılması ile mümkün olacağına inanan Bektaş, bunun ekonomik açıdan savunulabilir, çağdaş bir işlev verebilmekle mümkün olabileceğini ve aşırılığa kaçmayan onarımlarla ülke ekonomisine de katkı sağlanabileceğini belirtmektedir [5].

Büyük bir kısmı tarihi çevre içinde yer alan Urfa konutlarının kullanarak korunması için yeni işlevler verilebilmektedir. Bunlardan biri de konutların konukevi olarak kullanılmasına yöneliktir.

\subsection{Konukevi Kullanımının Çevresel Açıdan Değerlendirilmesi}

Kentin ilk yerleşim alanları ve çevresinde inşa edilmiş olan geleneksel Urfa konutları tarihi bir kent dokusu oluşturur (Şekil.21). $\mathrm{Bu}$ bölgede konukevine dönüştürülen geleneksel konutlar, 
konaklama amaçlı kullanımlarıyla yörenin tarih ve kültürünün tanıtılmasına ve kültür turizmine katkı sağlamaktadır.

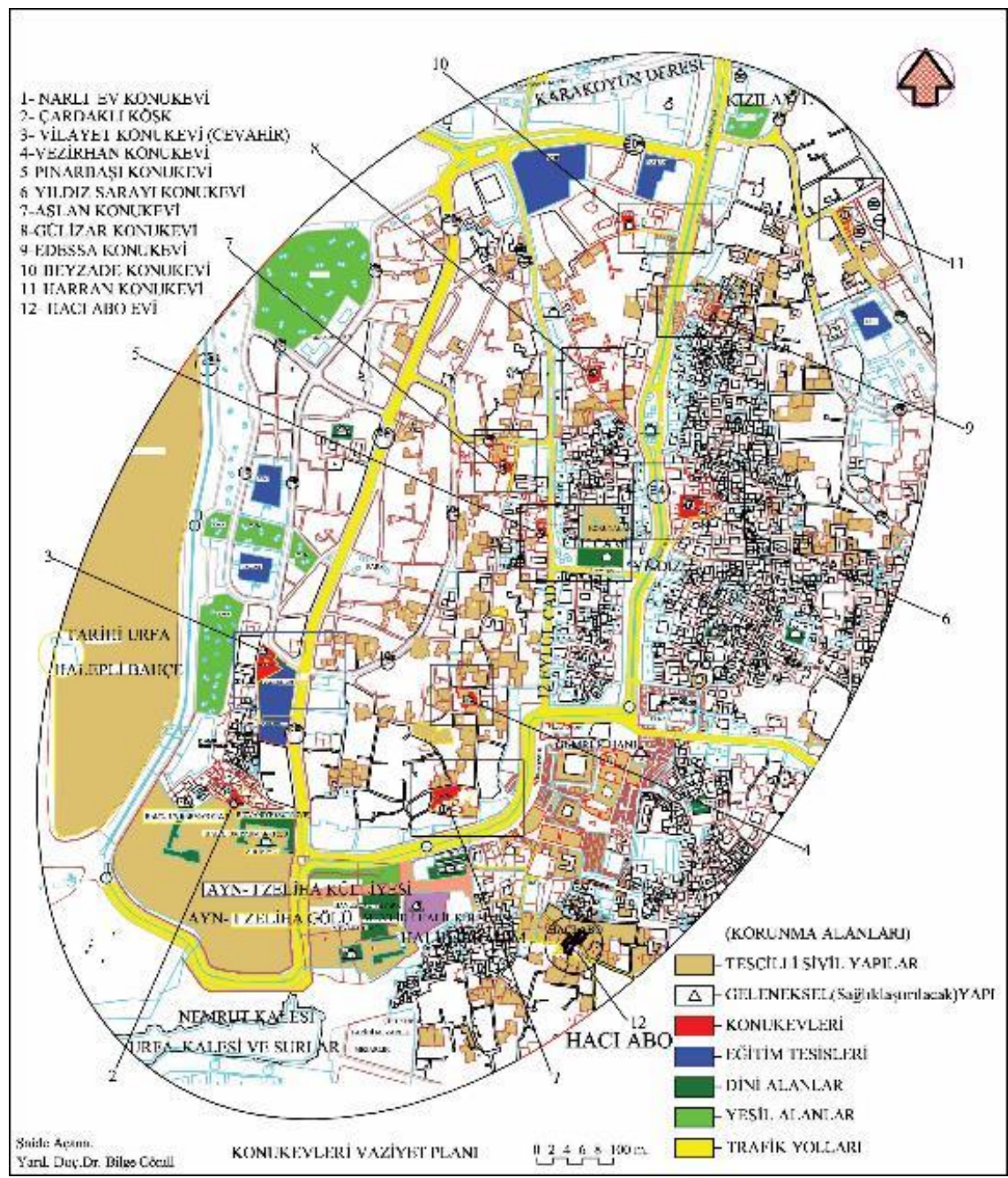

Şekil.21. Konukevleri ve çevresi, Tarihi Urfa Kenti Koruma Amaçlı İmar Planı, 2013

Kuban'a göre; yapılar tek tek veya birlikte dizildiği ve aralarında boşluklar oluşturulan şekliyle, kentsel tarihi çevre içinde bir düzen oluşturur. Kent; sokakları, bahçeleri, boşlukları ve boşluklara mekansal değer kazandıran yapılarla var olur. Bu sebeple mimari ve kentsel koruma yaklaşımları, kesin çizgiyle ayrılmaz. Yapıya müdahalelerde, bulunduğu çevre ile birlikte ele alınarak son şekline karar verilir [6]. 


\subsection{Konukevi Kullanımının Mekansal Açıdan Değerlendirilmesi}

Geçmişten bugüne, aile yapısı ve mekansal konfor yaklaşımlarının değişimiyle yeni kent merkezlerine yönelim, geleneksel Urfa konutlarının özgün işleviyle kullanımlarını zorlaştırmaktadır. $\mathrm{Bu}$ yüzden yapısal olarak çoğu yerde sağlıklı durumda olmasına rağmen kullanım dişı kalan konutların yeniden işlevlendirilerek topluma kazandırılması koruma kapsamında doğru bir yaklaşımdır. Konaklama yapısı olarak konukevlerinin mimari programı, geleneksel konutların mekan kurgusu ile uyumludur. Konutların çok odalı oluşu, açık, yarı açık ve kapalı mekanların sunduğu ortak kullanım imkanlarıyla, özgün yapının mimarisini koruyarak mekanlarda işlevsel adaptasyonun gerçekleştirilmesi mümkün olabilmektedir. $\mathrm{Bu}$ durum, koruma yaklaşımlarının mümkün olduğunca eklerden kaçınılması yönündeki ilkesine de uyum sağlayacaktır. Ek yapmanın kaçınılmaz olduğu durumlarda ise, Kültür ve Tabiat Varlıkları Koruma Yüksek Kurulunun kararı gereğince, "yeni işlev verilecek yapılarda yapılacak eklerin, niteliğinin korunması gerekli kültür varlığıyla bütünleşmesi gerekmektedir" düşüncesinden yola çıkılmalıdır [7].

Genellikle, konukevi işlevi verilen geleneksel konutlardaki plan şemasına göre; konutun giriş kısmı; lobi ve resepsiyon, mutfağı yine mutfak, odalar; yatak odaları ve çok amaçlı odalar, develik ve zerzembeler ise şark odaları ile çok amaçlı salonlar olarak kullanılacaktır. $\mathrm{Bu}$ durumda, genel mimari yap1 değişmeden, mekanların fonksiyon değişikliği, çağın teknolojisi ile birleştirilerek gereken işlev ve konforun sağlanması hedeflenmelidir.

Geleneksel Urfa konutlarının önceki kullanıcıları, konut sahipleriyken, bugün konukevine dönüş̧en yapılar çeşitli kültürlerden gelen insanlar tarafından kullanılmaktadır (Tablo.1). Yapının sahibi işletmeci, kullanıcıları ise yerel deyimiyle konuktur. Geleneksel konutlar ilk olarak kullanıcılarının aidiyet duygusu ile oluşan ve sürekli kullanımla biçimlenen bir mekan karakterine sahiptir. Konukevi kullanımı ise yapıya ticari bir işlev kazandırmıştır. Değişken kullanıcı kimliği konutun özgün aidiyet kimliğini ortadan kaldırmıştır. 
Tablo.1. Konutlar ve konukevleri analizi

\begin{tabular}{|c|c|c|c|c|c|}
\hline \multicolumn{6}{|c|}{$\begin{array}{l}\text { GELENEKSEL KONUTLAR VE KONUKLVLERI ARASINDAKI } \\
\text { MEKANSAL, ISLFVSEL BENZFRLIKLER VF FARKLAR }\end{array}$} \\
\hline \multirow[t]{3}{*}{ IYYI.IYMIIIR } & \multicolumn{2}{|c|}{$\begin{array}{l}\text { ORIJIXAL YAPI (KONUT) } \\
\text { (Konut Salipleri) }\end{array}$} & \multicolumn{3}{|c|}{ 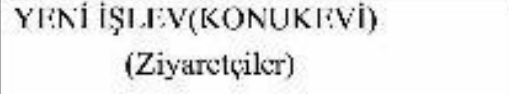 } \\
\hline & & \multirow[t]{2}{*}{ MEK $\triangle N L A R$} & & \multicolumn{2}{|c|}{ MEK $L N L A R$} \\
\hline & & & & MEVCUT & EKLENTI \\
\hline YAIMA & VAR & ODALAR & VAR & YATAKO. & DUS-WWC: \\
\hline $\begin{array}{l}\text { YEME IÇME } \\
\text { (HazıIlama) }\end{array}$ & VAR & $\begin{array}{l}\text { LYVAYLAK (Y:ZZ) } \\
\text { AVLLLAR (Yuz) }\end{array}$ & VAR & $\begin{array}{l}\text { ODALAR } \\
\text { LYVANLAR } \\
\text { AVLULAK }\end{array}$ & $\begin{array}{l}\text { COK AMACLI } \\
\text { KUI I.ANTM } \\
\text { (Tef:iş ile } \\
\text { Dönüsüim) }\end{array}$ \\
\hline DiNLLNML & VAR & TFRASI.AR (Yaz) & & TFRASI.AR & $\begin{array}{l}\text { AHSAPTAN } \\
\text { EKLENTI }\end{array}$ \\
\hline PișiRMF. & VAR & MUTFAK & VAR & MLTFAK & MEVCUT \\
\hline $\begin{array}{l}\text { YIKANMA } \\
\text { TFMIZI.F.NMIF }\end{array}$ & VAR & WYC.LAV. & $\mathrm{V}_{\mathrm{NR}}$ & WC. LAV. & $\begin{array}{l}\text { MEVCUT VE } \\
\text { iI.AVF }\end{array}$ \\
\hline \multirow{3}{*}{$\begin{array}{l}\text { SIRA } \\
\text { GECELERI VE } \\
\text { KÜLIC̈LLL } \\
\text { GAALIYETLERj }\end{array}$} & \multirow[t]{3}{*}{ VAR } & \multirow{3}{*}{$\begin{array}{l}\text { ODALAR } \\
\text { EYVANLAR (Yaz) } \\
\text { AVI.LILAR (Yaz) } \\
\text { TFRASI.AR (Yaz) }\end{array}$} & \multirow[t]{3}{*}{ VAR } & $\begin{array}{l}\text { ODALAR } \\
\text { FYVANI.AR } \\
\text { AVLLILAR }\end{array}$ & MLVCUT \\
\hline & & & & $\begin{array}{l}\text { DEVELIKLEK } \\
\text { LLELLMBLLLKR }\end{array}$ & $\begin{array}{l}\text { (Teffiş ile } \\
\text { Dönūsüim) }\end{array}$ \\
\hline & & & & TERASL_AR & $\begin{array}{l}\text { AHSAPTAN } \\
\text { EKLENII }\end{array}$ \\
\hline $\begin{array}{l}\text { YYYECEK VE } \\
\text { MAI Z.FME } \\
\text { DFPOI ANMASI }\end{array}$ & VAR & $\begin{array}{l}\text { ZFR7FWBEI.ER } \\
\text { (Kilerler, Oduatubliur) }\end{array}$ & VAR & $\begin{array}{l}\text { ODALARIN DEPO } \\
\text { AMAC,I.I } \\
\text { KLILLANIMII } \\
\text { SARK ODALART }\end{array}$ & 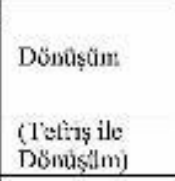 \\
\hline $\begin{array}{l}\text { BARINDIRMA } \\
\text { (HayYan) }\end{array}$ & VAR & DEVELIKLER & - & $\begin{array}{l}\text { COK AMACLI } \\
\text { KULLANIM } \\
\text { SARK ODALARI }\end{array}$ & $\begin{array}{l}\text { (Tet:ıs ile } \\
\text { Dönūșim) }\end{array}$ \\
\hline IDARI ISSI.ER & YOK & & VAR & $\begin{array}{l}\text { ODALAR } \\
\text { AVLU (KAPALI) }\end{array}$ & $\begin{array}{l}\text { (leftis ile } \\
\text { Dönuş:im) }\end{array}$ \\
\hline BEKLEME (LOBI) & YOK & & VAK & $\begin{array}{l}\text { ODALAR } \\
\text { AVI.U (KAPAT.J) }\end{array}$ & $\begin{array}{l}\text { (T\&f:iş ilc } \\
\text { Dönūşïm) }\end{array}$ \\
\hline
\end{tabular}




\section{4. "HACI ABO EVİ" NİN KONUKEVINE DÖNÜŞÜMÜNÜN MEKANSAL AÇIDAN DEĞERLENDİRESİ}

Hacı Abo kabaltısı içinde yer alan konut, Hacı Abo Evi olarak tanınmaktadır. Mimari karakterinin zenginliğiyle, geleneksel Urfa konutlarının ayrıcalıklı örneklerinden biridir. Diğerlerinden farklı olarak zemin katta yer alan giriş avlusunun üstü kapalıdır. Bu durum konukevi kullanımında faydaya dönüşecektir.

Kullanım dışı kalan Hacı Abo Evinin, çevresi, konumu, plan, cephe, yapısal ve mekansal özellikleri açısından uygun bir kullanım olarak değerlendirilen konukevine dönüştürülmesi koruma açısından doğru bir yaklaşım olarak değerlendirilebilir.

\subsection{Restorasyon Öncesi "Hacı Abo Evi"}

Şanlıurfa ili, merkez tepe mahallesi, pafta 66, ada 385, parsel 6 'da kayıtlı bulunan konutun girişi, Hacı Abo kabaltısı içinde, kuzeybatıdan güneydoğu yönüne doğru çıkan yolun sağ tarafinda bulunmaktadır. Aile yakınlarından edinilen bilgilere göre, Fesçizade ailesinden olan Hacı Abo (Abdurrahman),1736 yılında Bağdat' tan Urfa'ya gelen bir zattır. Konutun Hacı Abo soyundan gelen kişiler tarafından yaptırılmış ve kullanılmış olduğu tahmin edilmektedir. Yapının tarihi ile ilgili bilgiler bulunmamaktadır. Konutta herhangi bir kitabeye de rastlanmamıştır.

Yapısal ve mekansal niteliklerinden, tonozlu kısımların ve mertekli tavanların 18.yüzyıl ortalarında, birinci kattaki ahşap tavanların ve çatılı kısımların 19.yüzyıl sonları ve 20.yüzyıl başlarında yapıldığ tahmin edilmektedir. Süreç içinde yapıda onarımlar gerçekleşmiştir. İzlerden anlaşıldığına göre; mülkiyet dışı kalan üç bölüm ve Hacı Abo Evinin bugünkü sınırlarını oluşturan dördüncü bölüm bulunmaktadır (Şekil.22). 


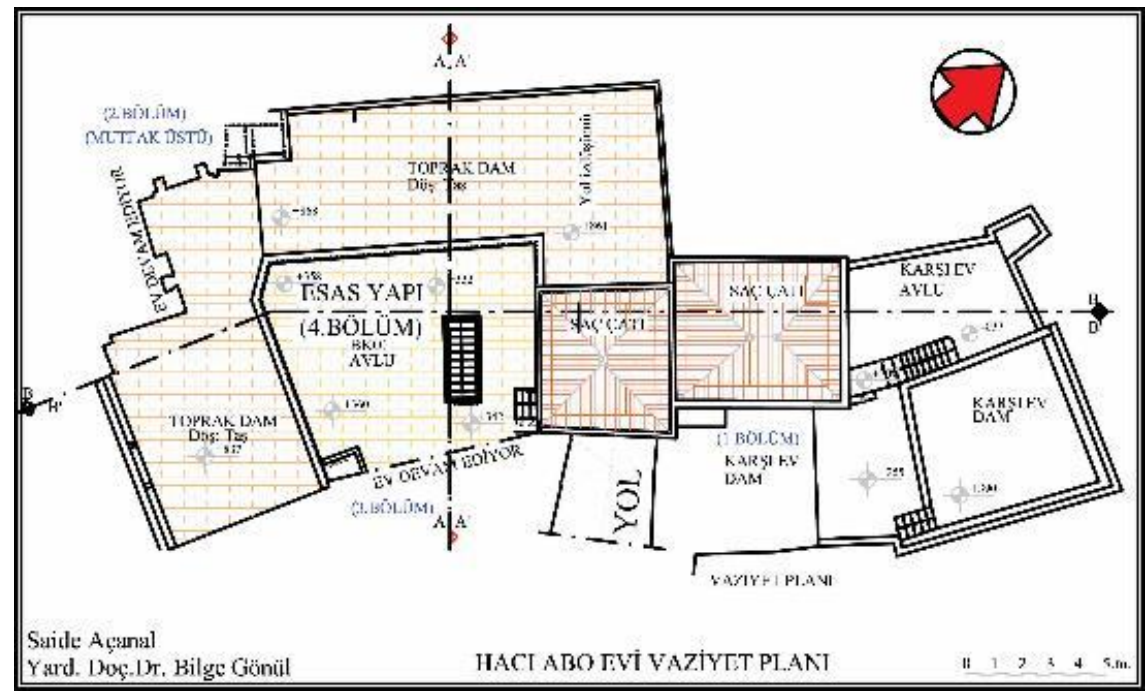

Şekil.22. Hacı Abo Evi ve mülkiyet dışı kalan bölümlerin konumu

Birinci bölümün; kuzeydoğuda bulunan ve çıkışa göre yolun solundaki kapıdan girilen karşı konutun, Hacı Abo Evinden ayrılan bir parça olduğu anlaşılmaktadır. Şöyle ki; konutun kuzeydoğusunda bulunan eyvandan, 7-8 basamakla inilerek ulaşılan odanın karşı duvarında bulunan mevcutta kapatılmış olan bir kap1, karş1 konutun avlusuna açılmaktadır ve buradan bir merdivenle o bölümdeki avluya inilmektedir. $\mathrm{Bu}$ kısım önceleri bölünerek mülkiyetten çıkartılmıştır ve bu bölümde, hizmetlilerin kaldığı bilinmektedir.

İkinci bölüm; Hacı Abo Evinin güneybatısındaki konutun bir kısmının mutfak üzerinde olması ve izler, bu konutun devamı olduğunu göstermekte, mutfağın küçük olması da bu düşünceyi kuvvetlendirmektedir.

Üçüncü bölüm; avlunun doğusunda bulunan ve sonradan yapılmış olduğu belli olan, avluyu ve konutu ikiye bölen duvarın diğer tarafındaki kısımdır ve bu bölümün de başlangıçta bu konuta ait olduğu izlerden anlaşılmaktadır.

Dördüncü bölüm; Hacı Abo Evinin bugünkü sınırlarını oluşturmaktadır. Alt ve üst avlu ile konutun en geniş alana sahip ve en karakteristik bölümüdür. Tapu bilgilerinde $410 \mathrm{~m}^{2}$ olan yapıya, Balıklıgöl'ün doğusundaki tarihi sokaklardan geçilerek ulaş1lır (Şekil.23). Sınırları düzgün olmayan parsel üzerine, bitişik nizam olarak inşa edilen yapı iki katlıdır. 
Konutun yer aldığı kabaltı, beşik tonoz ve çapraz tonoz örgü sistemiyle inşa edilmiş olup, Urfa'nın en uzun kabaltılarındandır. Bu konutun önemli özelliklerinden biri ise, kuzey yönünde, ara katta ve üstünde yer alan odanın sokağın karşı tarafında bulunması (karşı evin mutfağının üzerinde), kuzey eyvanı ve avlunun kuzeybatı köşesindeki odanın ise sokağı örten kabaltı üzerinde yer almış olmasıdır. Bu özellik, sokağa biçim, hareket ve cephe zenginliğiyle birlikte, konut için de yol cephesinden yararlanma olanağı sağlamıştır (Şekil.23).

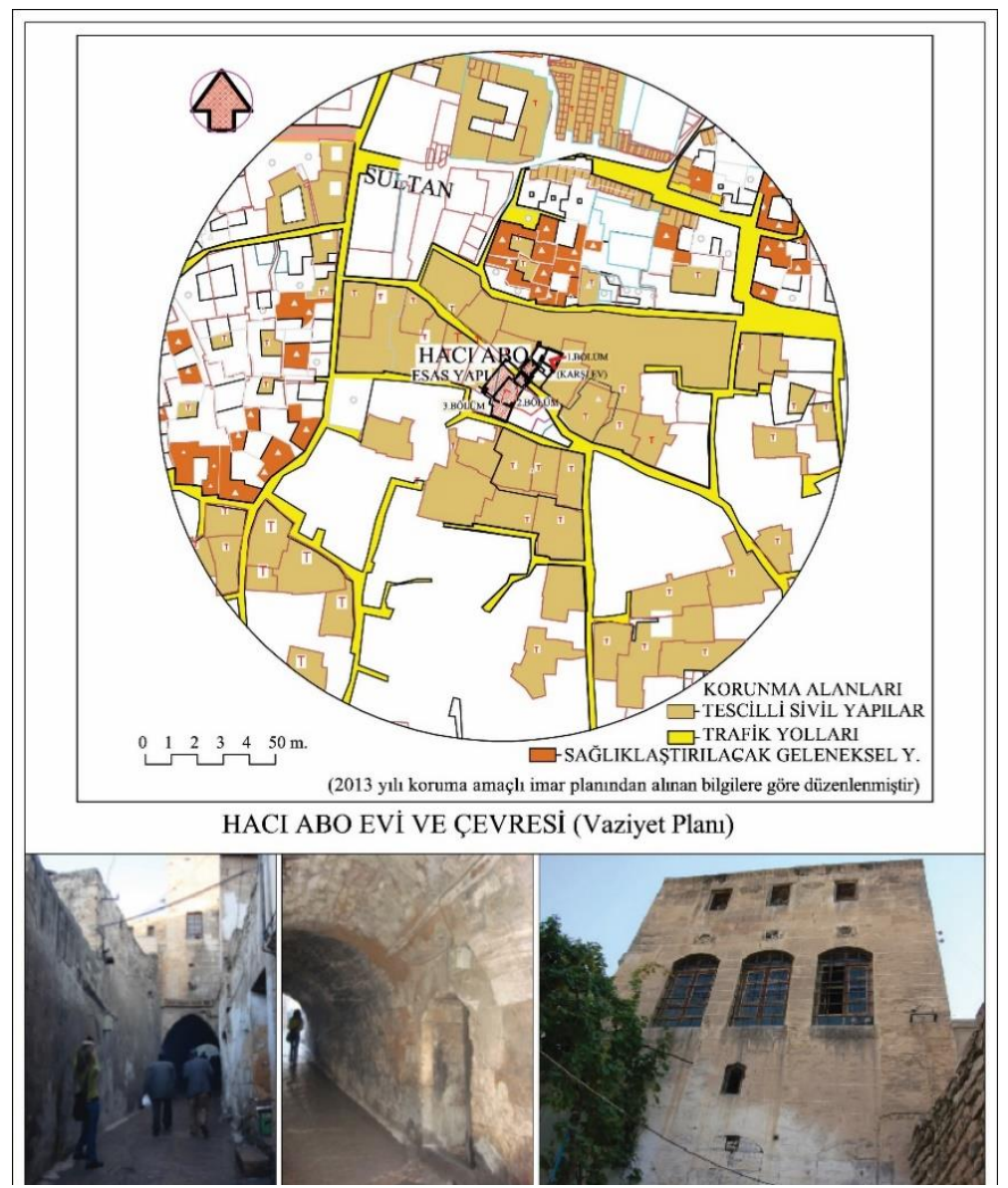

Şekil.23.a. Tarihi Urfa Kenti Koruma Amaçlı İmar Planı üzerinde Hacı Abo Evi

Şekil.23.b. Hacı Abo Evi Kabaltısı; Şekil.23.c. Hacı Abo Evi Konut Girişi; Şekil.23.d. Hacı Abo Evi Kuzey Batı Cephesi (Ara kat üstü) (S. Açanal Arşivi, 2006) 
Hacı Abo Evinin $100 \mathrm{~m}^{2}$ lik alana sahip zemin katında(selamlık); kapalı bir avlu, iki oda, tuvalet, lavabo ve merdiven bulunmaktadır (Şekil.24). Konutun girişinin yer aldığı zemin kattaki kapalı avludan, birinci kattaki esas avluya merdivenle bağlantı sağlanmaktadır. Kapalı avlunun ve odaların havalandırması esas avluya açılan boşluklarla sağlanmaktadır.

$285 \mathrm{~m}^{2}$ lik bir alana sahip olan birinci kat (harem); açık bir avlu, iki eyvan, bir mutfak, kuyu ve odalardan oluşmaktadır (Şekil.25). Ara katta bir oda yer almaktadır. Avlunun batı yönünde üç adet oda bulunur. Bunlardan mutfağa yakın olan odanın içinde, diğerlerinden farklı olarak banyo yer alır. Odaların avluya bakan cephelerinde, pencere üstlerinde kör taka ve havalandırma takaları bulunmaktadır. Avluya açılan eyvanların biri güneyde olup, cephesi kuzeye yönlendirilmiştir ve yazlık kullanıma uygundur. $\mathrm{Bu}$ eyvandan ulaşılan bir oda ve batısında mutfak bulunur. Avlunun kuzeyindeki diğer eyvanın cephesi güneye yönlendirilmiştir ve kışlık kullanıma uygundur. Kuzey eyvanının iç duvarlarındaki bezemeler ve sakallı kemer olarak bilinen açıklığın en üst noktasından aşağı sarkan özgün motif (şebekeli oyma) dikkat çekicidir. $\mathrm{Bu}$ eyvandan ulaşılan kuzeydeki odanın altında ara katta yer alan odada, hizmetli evine açılan kapının izleri yer alır. Kuzeybatıdaki oda kapısının hemen yanında, kuzeydeki eyvanın solunda kuyu vardır. Birinci kattaki avlunun doğusunda, izlerden sonradan yapıldığı anlaşılan, avluyu ve konutu ikiye bölen duvar bulunmaktadır (Şekil.25).

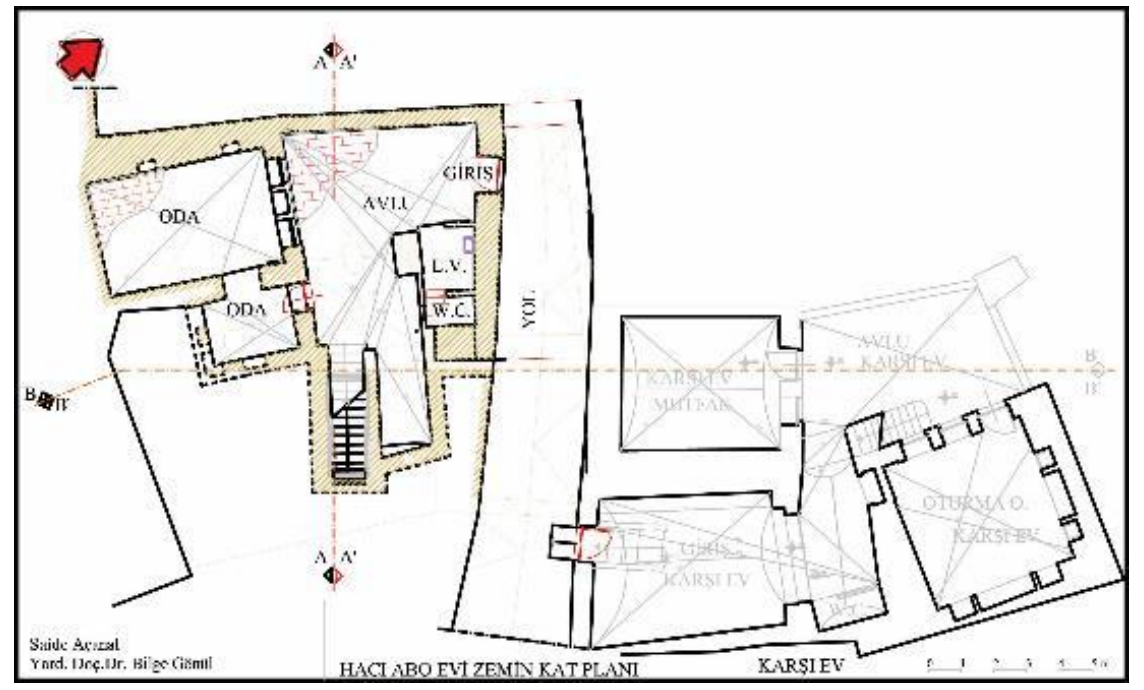

Şekil.24. Hacı Abo Evi, zemin kat planı (Selamlık)-rölöve 


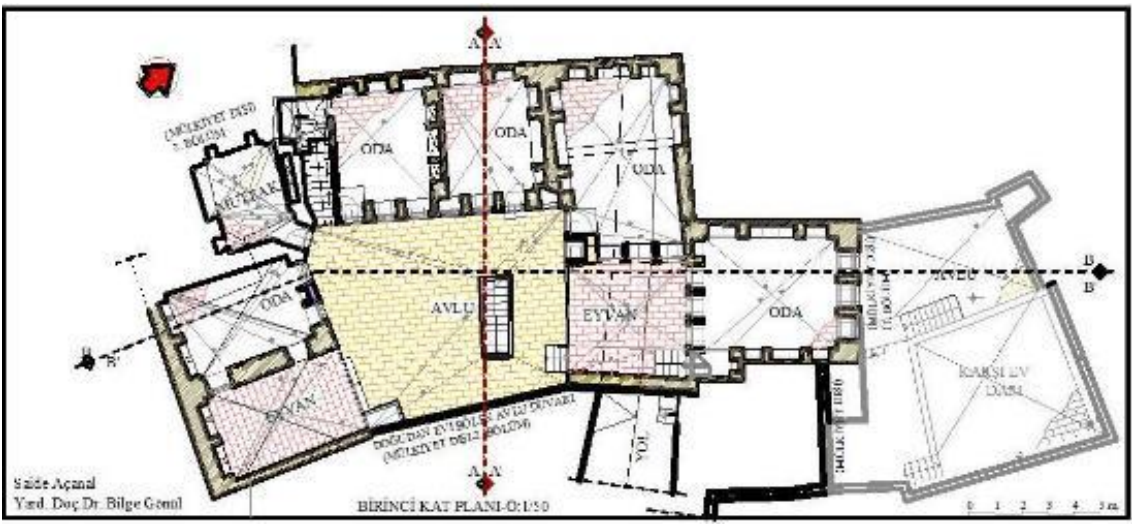

Şekil.25. Hacı Abo Evi,birinci kat planı (Harem)-rölöve

Hacı Abo Evi, yığma taş yapım sistemi ile inşa edilmiştir. Üst örtü olarak tonozlu, mertekli düz çatı (dam) ve eğimli çatı sistemi uygulanmıştır (Şekil.26).

Zemin kattaki avluda, beşik tonoz ve yıldiz tonoz bir arada kullanılmış, tonoz sistemle kapatılan odalarda yıldız tonoz kullanılmıştır. Tüm duvarlar kalın ve nişlidir. Birinci kattaki avlu ve kuzeydeki odanın tabanı taş, diğer odalar ve teras çatı olan damların tabanı şaptır.

Birinci katta kuzeydeki odanın gedemeç tavanı aynalı ahşap, oda tavanı motifli ahşap kaplamalıdır. Avludan dama çıkan merdivenin üstü içten ahşap mertekli ve sağlam görünümlüdür.

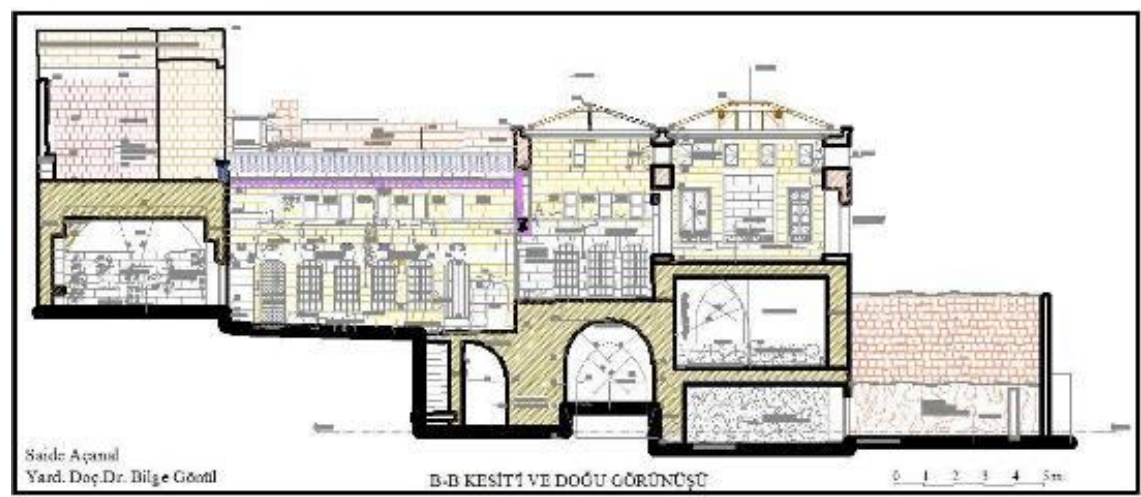

Şekil.26. Hacı Abo Evi-Doğu görünüşü ve B-B kesiti (rölöve) 


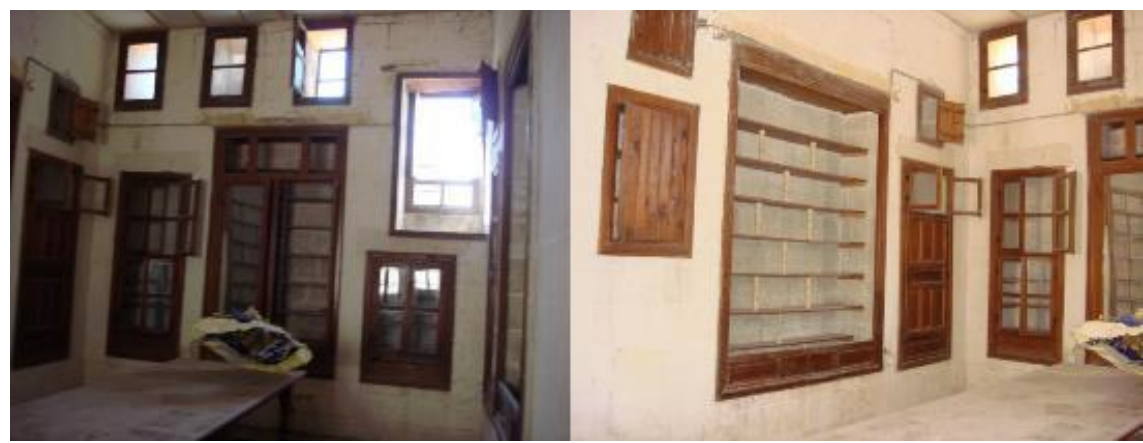

Şekil.27. Odaların iç mekanları (S. Açanal Arşivi, 2007)

Odalar üst katta, alt kattakilere oranla daha yüksek tavanlıdır. Üst kattaki odaların, zeminden bir basamak düşük kotta, ayakkabıların çıkarıldığ 1 ve duvarda nişleri olan, kare planlı gedemeçleri vardır.

Odaların duvarlarındaki camlı ve camsız ahşap doğramalı veya kepenkli camhaneler, dolap nişleri ve üst pencereler karakteristiktir (Şekil.27).

Hacı Abo Evi zengin bezemeleri olan bir yapıdır (Şekil 28). Üst avlunun batı cephesinde yer alan rozetlerin her biri farklı motifler şeklindedir. Kuzey eyvanında kemer süslemeleri ve eyvanın iki yanındaki sütunlarda nakışlı taş süslemeler bulunmaktadır.

Hac1 Abo Evinin, dört bölüme ayrılmış olması, mevcut durumun mekan sayısı ve büyüklükleri, mimari elemanlar ve bezemeler dikkate alınarak, ekonomik düzeyi yüksek, kalabalık ailelere göre inşa edilmiş olduğu anlaşılmaktadır.

Mekansal açıdan yapılan değerlendirmeler, konutun yörenin kültürel ve yapısal özellikleriyle biçimlenmiş ayrıcalıklı bir yapı olduğunu göstermektedir. 


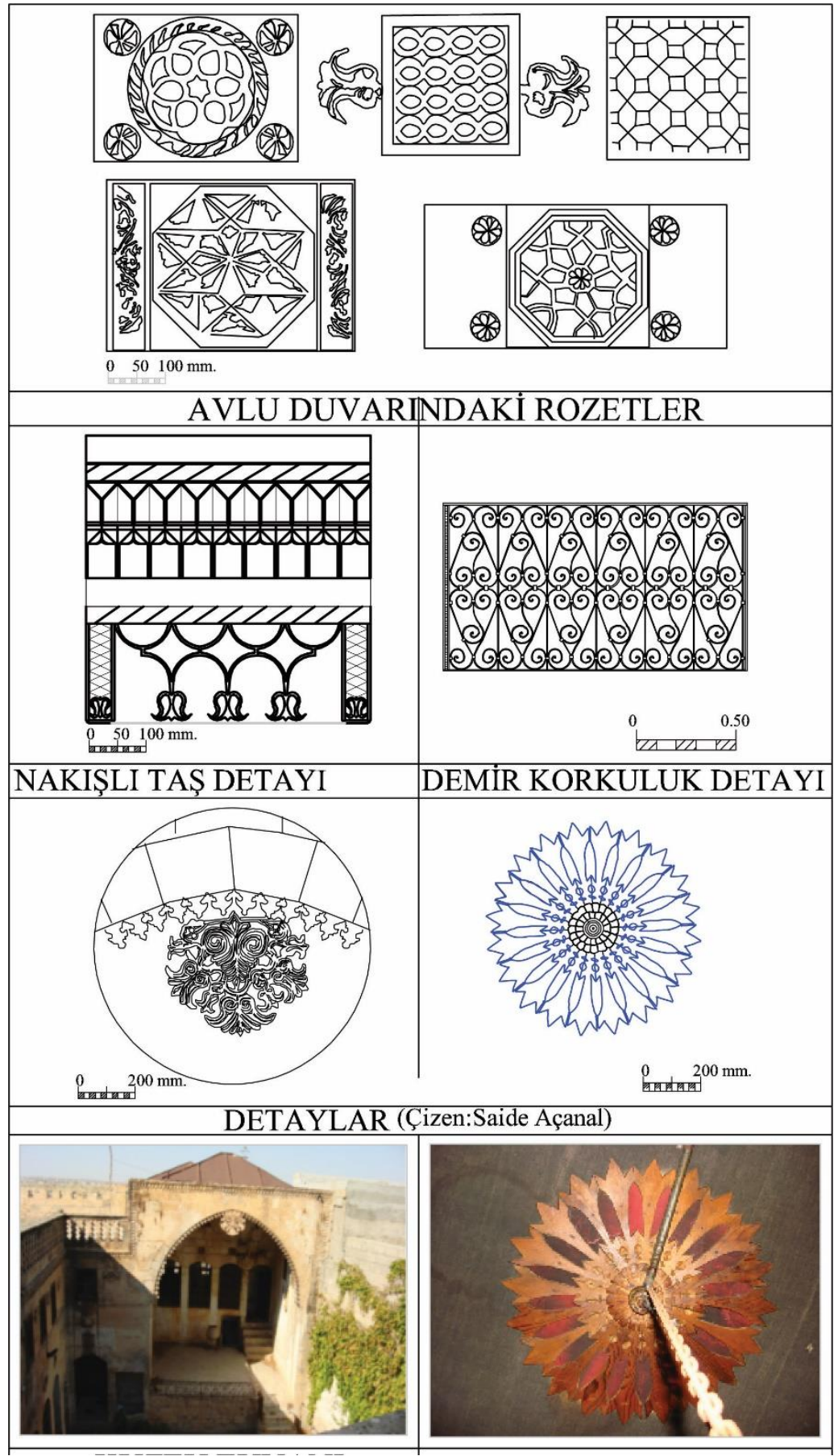

Şekil 28. Bezemeler 


\subsection{Restorasyon Sonrası "Hacı Abo Evi"}

2014 tarihinde hazırlanan restorasyon projesi incelendiğinde elde edilen bilgiler ve yerinde yapılan incelemeler ışığında aşağıdaki sonuçlara varılabilir;

2006 - 2007 yıllarına kadar konut olarak kullanılan, daha sonra terkedilerek yıpranmaya başlayan yapının yeniden işlevlendirilmesiyle kullanılarak korunması hedeflenmektedir. Şanlıurfa'da gelişen kültür turizmine yönelik bir eğilim olarak geleneksel konutlar konukevine dönüştürülmektedir. Bölgenin kültürel değerlerinin yaşatıldığı bir konaklama yapısı olarak, Hacı Abo Evinin konukevine dönüşümü doğru bir yaklaşım olarak değerlendirilmektedir.

Tarihi yapılara verilecek yeni işlevin, yapılı çevreyle uyum içinde olması beklenir. Kentin ilk yerleşim bölgesi olan tarihi çevre içinde yer alması, benzerlerinin yanı sıra, Hacı Abo Evinin de konukevi olarak kullanımının gereken çevresel uyumu sağlayacağını düşündürmektedir.

Konukevine dönüştürülen geleneksel konutlarda, yapısal ve mekansal değişime ihtiyaç duyulmadan işlevsel adaptasyon söz konusu olabilmektedir. Özgün değerlerin korunması, söz konusu konukevi kullanımında kullanıcının mekansal beklentilerini karşılaması açısından istenen bir durumdur. Böylelikle korumaya yönelik yaklaşım, süreklilik içerecektir.

Planimetrik açıdan yeni işlevin özgün işleve uyumu, mekansal ihtiyaçların benzerlik göstermesiyle kolaylaşacaktır. Hacı Abo Evinin ilk yapıldığı tarihe göre bir kısmı mülkiyet dışı kalmış olmasına rağmen, mevcut durumun oda sayıları, mekan büyüklükleri ile konukevi işlevine uygun olacağı düşünülmüştür. Buna göre, özgün konutun selamlık bölümünü oluşturan zemin katta girişte yer alan kapalı avlu konukevi kullanımında; lobi ve resepsiyon, odalar ise; idari bölüm ve şark odası olarak planlanmaktadır. Tuvalet ve lavabo yine aynı fonksiyonu sürdürecektir (Şekil.29). 


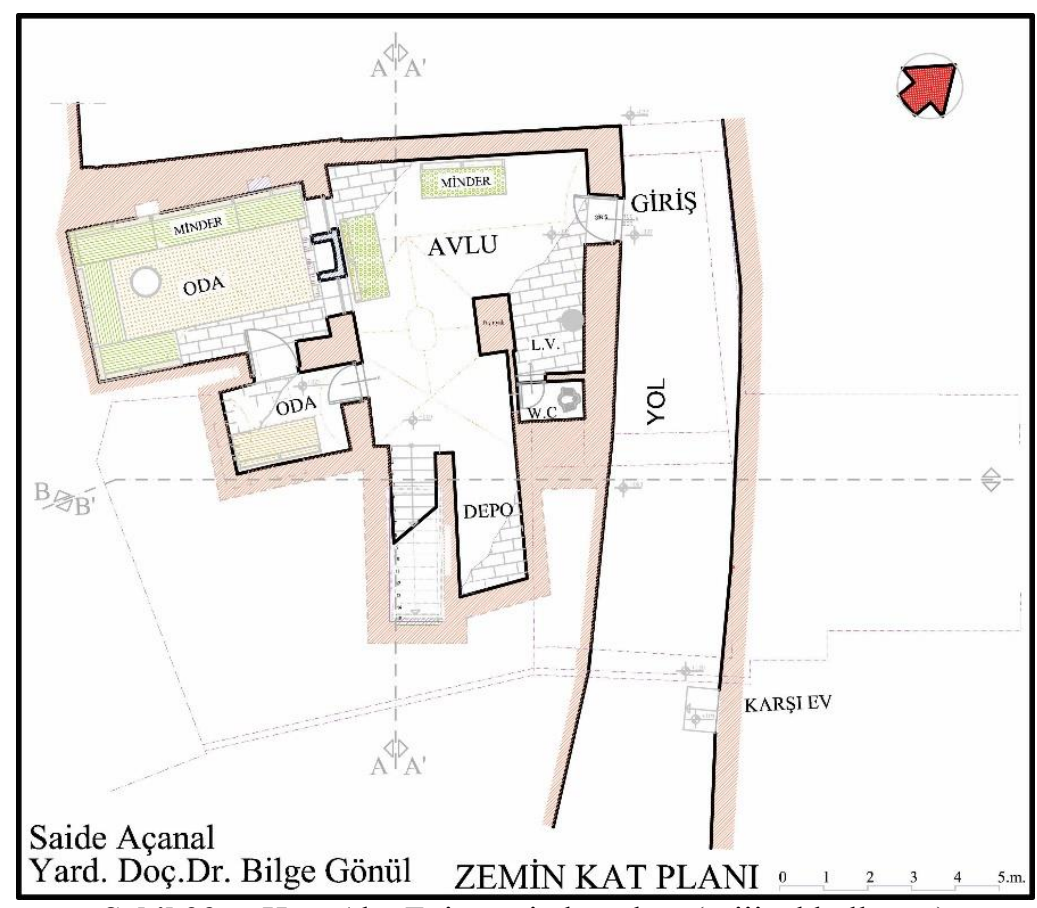

Şekil.29.a. Hacı Abo Evi, zemin kat planı (orijinal kullanım)

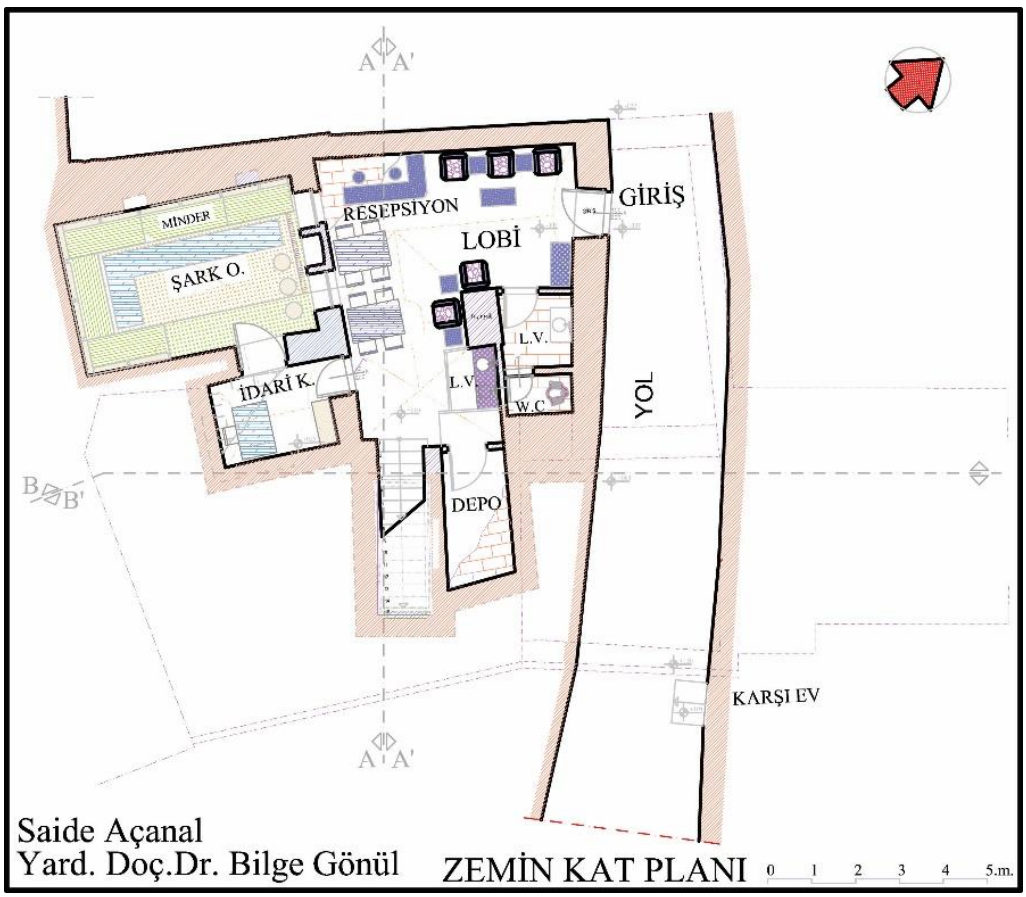

Şekil.29.b. Hacı Abo Evi, zemin kat planı (restorasyon önerisi) 


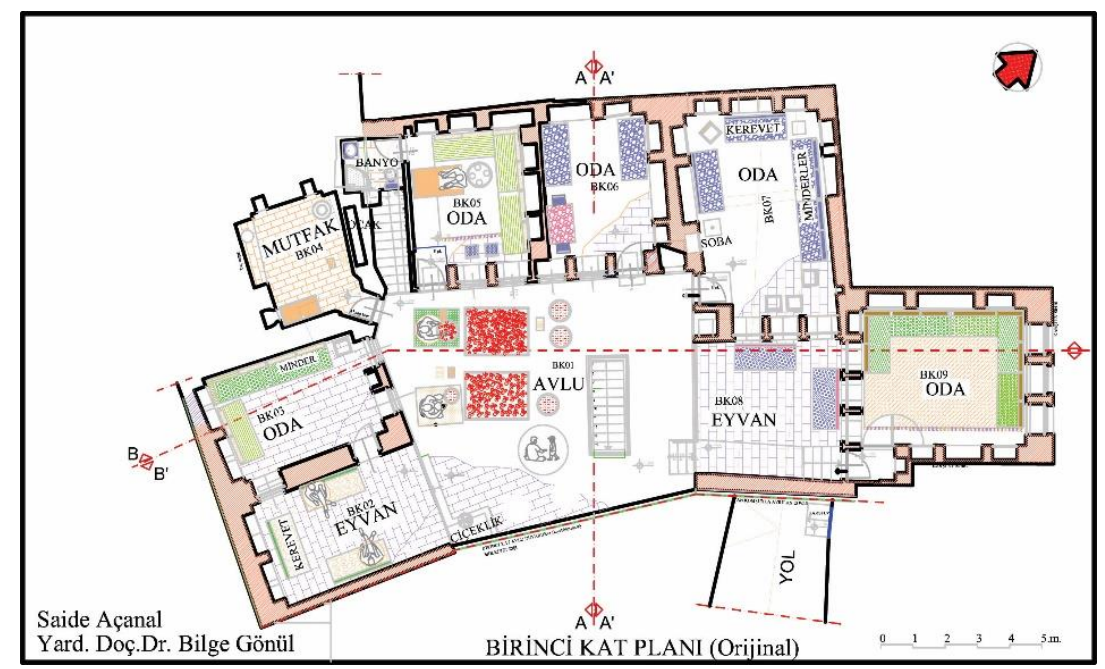

Şekil.30.a. Hacı Abo Evi, birinci kat planı (orijinal kullanım)

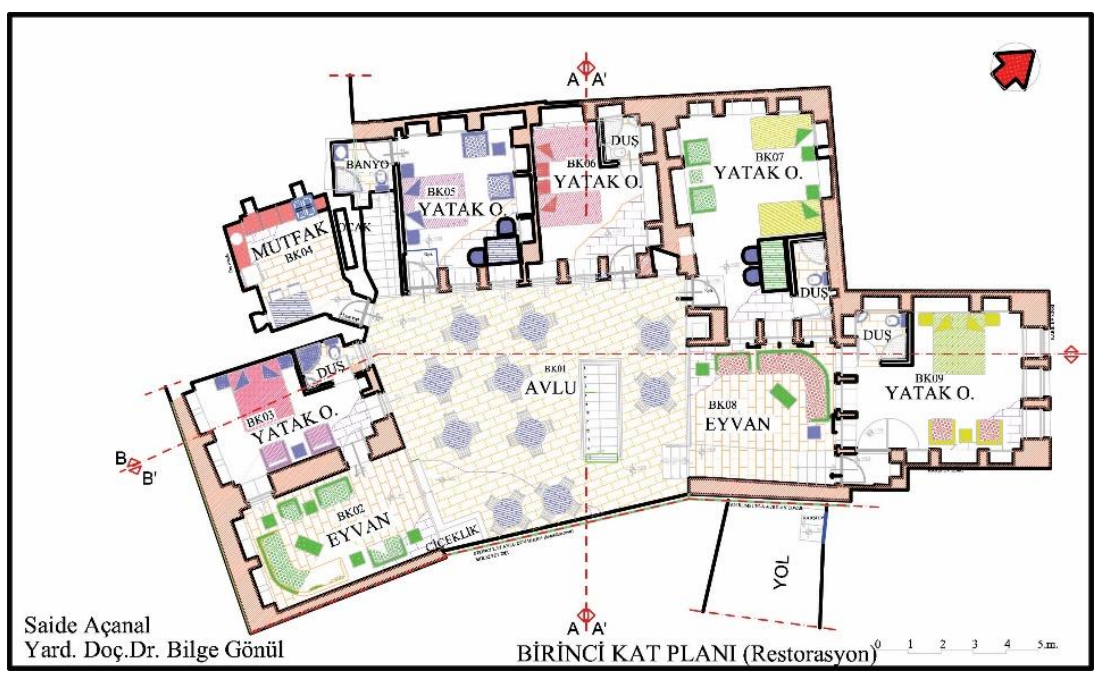

Şekil.30.b. Hacı Abo Evi, birinci kat planı (restorasyon önerisi )

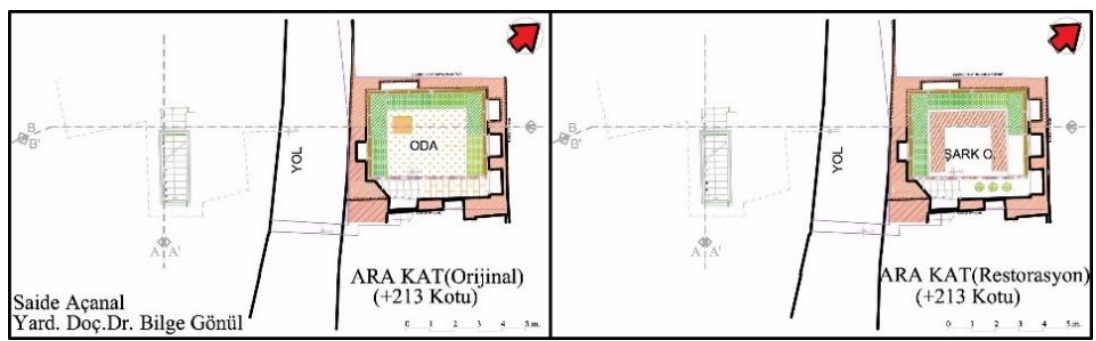

Şekil.30.c. Hacı Abo Evi, ara kat planı, orijinal kullanım ve restorasyon önerisi 
Hacı Abo Evi, yapısal ve mekansal nitelikleri, dolap nişleri ve camhaneler gibi mimari elemanlar ve bezemelerle karakteristik bir yapıdır. Zamanla yıpranan konutta yapısal onarımlar dışında, konukevi işlevine yönelik büyük değişimler gerekmeyecektir. Odalarda 1slak mekan eklentisi, hareketli donatılar ve bazı teknik destekler söz konusu olacaktır. Orijinal banyosu olan odada ıslak mekan eklenmesine ihtiyaç duyulmayacaktır.

Yapının kalın duvarları sayesinde, iç mekanda ısı ve ses yalıtımına ihtiyaç duyulmamaktadır. Bunun yanında konukların rahat edebilecekleri konforu sağlama açısından, yapıyı bozmadan, ısıtma, soğutma sistemleri ve internet gibi hizmetlerde çağın teknolojisinden yararlanılacaktır.

Konutta sonradan eklenen, özensiz nitelikteki kapı ve pencereler, özgün yap1 karakterine uygun olarak yenilenmelidir. Hasarlı durumda olanlar aslına uygun biçimde onarılmalıdır. Sokak kapısının, aynı formda ve malzemeden yeniden yapılması gerekmektedir. Birinci kattaki pencere doğramaları sağlam ve niteliklidir, bu yüzden bakım sağlanması yeterli olacaktır. Tüm ahşap doğramaların, camhane ve kepenklerin temizlenip ahşap koruyucu boya ile boyanmasına ihtiyaç vardır. Ahşap olan eskimiş tavanlar aynı malzeme ile yenilenmelidir. Düzensiz olan merteklerin kapatılarak ahşap tavan yapılması uygun olacaktır. Eyvana bağlı kuzey doğudaki üst odanın tavanı ise, aynen muhafaza edilmelidir. Oda girişinde bulunan aynalı tavan ise yine ahşap koruyucu ile boyanarak korunmalıdır. Demir korkuluklar sağlamdır ve temizlenip boyanmas1 yeterlidir.

Üst avluda ve eyvan duvarlarında bulunan rozetlerin, eyvanın iki yanındaki sütunlarda ve dam çatı döşeme altındaki nakışlı taş süslemelerinin bazıları kırıktır ve yeniden yapılarak yerine konulması, duvar yüzeylerinin raspa yapılıp derzlerinin tamamlanması gerekmektedir. Yalıtım yapılarak, damların (teras çatı) üzeri taş ile kaplanmalıdır (Şekil.31). 


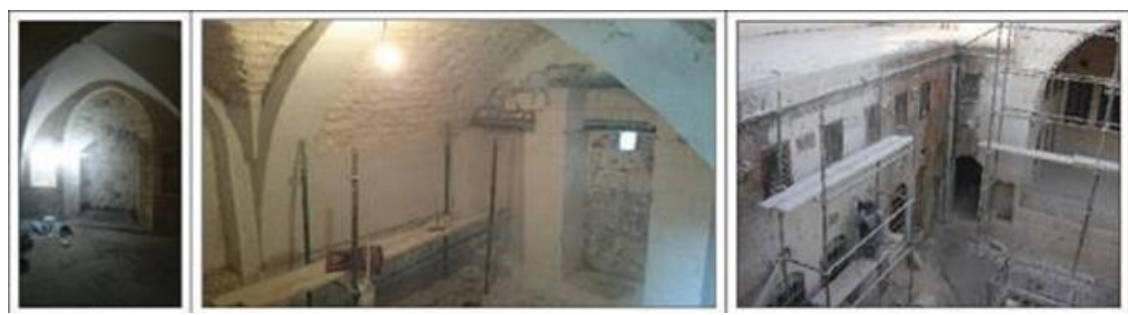

Şekil.31. Hacı Abo Evi zemin, ara ve birinci kat restorasyon çalışmaları, (S. Açanal Arşivi,2014)

\section{SONUÇ VE DEĞERLENDİRME}

Geleneksel Urfa Konutları kalabalık ailelere göre planlanmış olduğundan mekansal olarak; oda sayıları fazla, eyvan ve avlularıyla geniş alana yayılan, estetik değeri yüksek bezemeleriyle bölgenin mimari kimliğini yansıtan nitelikli yapılardır. Zaman içinde geniş aileler yerine çekirdek aile yapısının etkin olması geleneksel konutlarda yaşamaya devam edenlerin yapılarda çok az bir bölümün kullanılarak diğer kısımlarının bakımsız kalmasına sebep olmuştur. Bir diğer yandan, modern kent yaşamının cazip hale gelmesiyle bazı konutlar tamamen terk edilmektedir. Kullanım dışı kalmasına rağmen, yapısal olarak sağlam olan tarihi yapıların yeniden işlevlendirilerek kullanılması koruma açısından doğru bir yaklaşımdır. Geleneksel Urfa konutlarının işlev değişikliği kapsamında, konukevleri ile resmi kurum ve kuruluşlara yönelik kullanımlar tespit edilmiştir.

Geleneksel Urfa konutlarının karakteristik özelliklerinin korunuyor olması konukevi kullanımı için önemli bir değer oluşturmaktadır. $\mathrm{Bu}$ işlev değişikliğinin tarihi çevre içinde yer alan konutlarda gerçekleşmesiyle çevresel açıdan uyum sağlanmış olacaktır. Ayrıca konutun mekansal kurgusunun konukevinin ihtiyaçlarına karşıllı verebilmesi yeniden işlevlendirilen tarihi yapılarda hedeflenen bir durum olarak büyük değişimleri gerektirmeyecektir.

Hac1 Abo Evinde olduğu gibi, bölgenin kültür turizmine önemli bir katkı sağlayan konukevi kullanımı ile, geleneksel Urfa konutları sahip olduğu tarihi değerler korunarak ve farkındalığı arttırılarak yaşamını sürdürecektir. 


\section{KAYNAKLAR}

[1] Karlıklı, Ş. ve Ertem E. (1998). Suyla Yeniden Doğan Kent: Şanlıurfa. İstanbul: Creative Yayıncılık.

[2] Akkoyunlu, Z.(1989) "Geleneksel Urfa Evlerinin Mimari Özellikleri', Kültür Bakanlığı Yayınları 11: S:113-118.

[3] Kürkçüoğlu, A. C ve Sarıfakioğulları, H. (2002). Adım Adım Şanlıurfa, ŞanlıurfaValiliği Kültür ve Turizm Yayınları. S:59.

[4] Küçükerman, Ö. (1995) " Anadolu Mirasında Türk Evleri", Aksoy, Grafik Dizgi Matbaacılık Anonim Şirketi, İstanbul; S:95.

[5] Bektaş, C. ( 1992). Koruma Onarım. Birinci Baskı: Y. E. M. Yayın. Yapı-Endüstri Merkezi, Yayın Bölümü. Halaskargazi Caddesi No: 115 Kat: 6. Harbiye 80230 İstanbul, S:111

[6] Kuban, D.(2000). Tarihi Çevre Korumanın Mimarlık Boyutu- Kuram ve Uygulama- Birinci Baskı, YEM Yayın (Yapı-Endüstri Merkezi Yayınları). Cumhuriyet Cad. 329 Harbiye 80230 İSTANBUL, S:120

[7] (660 nolu İlke Kararı) Taşınmaz Kültür Varlıklarının Gruplandırılması, Bakım ve Onarımları, T. C. Kültür Bakanlığı Kültür ve Tabiat Varlıklarını Koruma Yüksek Kurulu (1999). http://teftis.kulturturizm.gov.tr/TR,14330/660-nolu-ilkekarari-tasinmaz-kultur-varliklarinin-grup-.html(15.8.2014) 